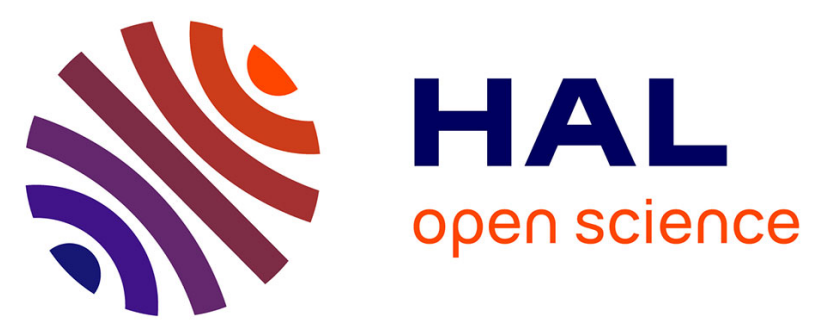

\title{
Structural modeling based on sequential restoration of gravitational salt deformation in the Santos Basin (Brazil)
}

Savio Francis de Melo Garcia, Jean Letouzey, Jean-Luc Rudkiewicz, André Danderfer Filho, Dominique Frizon de Lamotte

\section{To cite this version:}

Savio Francis de Melo Garcia, Jean Letouzey, Jean-Luc Rudkiewicz, André Danderfer Filho, Dominique Frizon de Lamotte. Structural modeling based on sequential restoration of gravitational salt deformation in the Santos Basin (Brazil). Marine and Petroleum Geology, 2012, 35, pp.337-353. 10.1016/j.marpetgeo.2012.02.009 . hal-01134814

\author{
HAL Id: hal-01134814 \\ https://hal.science/hal-01134814
}

Submitted on 24 Mar 2015

HAL is a multi-disciplinary open access archive for the deposit and dissemination of scientific research documents, whether they are published or not. The documents may come from teaching and research institutions in France or abroad, or from public or private research centers.
L'archive ouverte pluridisciplinaire HAL, est destinée au dépôt et à la diffusion de documents scientifiques de niveau recherche, publiés ou non, émanant des établissements d'enseignement et de recherche français ou étrangers, des laboratoires publics ou privés. 


\section{Elsevier Editorial System(tm) for Marine and Petroleum Geology Manuscript Draft}

Manuscript Number:

Title: Structural modelling based on sequential restoration of gravitational salt deformation in the Santos Basin (Brazil)

Article Type: Original Research Paper

Keywords: Salt tectonics; section restoration; Santos Basin; passive margin; South Atlantic; deep offshore.

Corresponding Author: Mr. Sávio Francis de Melo Garcia, M.Sc.

Corresponding Author's Institution: Petrobras

First Author: Sávio Francis de Melo Garcia, M.Sc.

Order of Authors: Sávio Francis de Melo Garcia, M.Sc.; Jean Letouzey, PhD; Jean-Luc Rudkiewicz, PhD; André Danderfer, PhD; Dominique Frizon de Lamotte, PhD

Abstract: Structural restoration and basin modelling tools enable to evaluate complex sedimentary basins such as the ones extending along the South Atlantic Brazilian margin. Several structures result from a complex 3D evolution and most commercial algorithms usually consider vertical backstripping solutions, even when the basin evolution is controlled by gravitational instabilities and horizontal tectonic transport. Salt tectonics actually, promotes lateral gliding of the overlying sedimentary pile, whereas poor paleo-bathymetric data increase uncertainty and difficulty of any restoration. Crosssections restoration is proposed, at first, to establish an easier understanding of the 3D geological complexities and to provide guidelines to handle more complex solutions. Two sections extending from the platform to deep waters of the Santos Basin, south-eastern offshore Brazil, have been chosen in areas where salt tectonics is simple enough to be solved by 2D restoration. These sections comprise both extensional and compressional deformation. Regional settings were important to establish the constraints applied on basic boundary conditions such as the overall paleo-bathymetry, the isostatic regional compensation, the salt volume control and the overall aspects related to structural style. Many restoration methods (simple shear, flexural slip and free methods) were used to restore the sedimentary deformation, including the salt gravity gliding. The $2 \mathrm{D}$ restoration results are consistent with five major sequences of sedimentary evolution: (1) the mechanical brittle pre-salt deformation, (2) the significant and fast salt deposition, (3) the initial post-salt deformation with predominant rafting tectonics, (4) the Late Cretaceous progradation sequence and coeval compressional evolution of minibasins, and (5) the Cenozoic sequence with less intense salt tectonics. A 1D subsidence analysis based on the 2D restored results is shown as a useful restoration control tool. The 1D results suggest a general proximal to distal filling controlled by salt tectonics. They also allow further discussion about areas with large horizontal gravity salt gliding.

Suggested Reviewers: Mark Rowan

Rowan Consulting, Inc., Boulder, CO

mgrowan@frii.com

He has work for a long time with the paper subject

Bruno Vendeville 
Université Lille 1

bruno.vendeville@univ-lille1.fr

He has work with salt tectonics

Chang H Kiang Ph.D

Professor, Geologia, Universidade Estadual de Rio Claro

chang@rc.unesp.br

He is one that knows well the Santos Basin.

John R Underhill Ph.D

Professor, Chair of Stratigraphy, University of Edinburgh

jru@staffmail.ed.ac.uk

Underhill supervised the Ph.D thesis of Marta Guerra, 2008, also about the Santos Basin. 
Research Highlights

\section{Research Highlights}

We reconstructed the evolution through time of two sections in salt complex area.

The restoration shows the geometry of 14 steps from Aptian to present.

Our approach integrates isostasy, bathymetry and deformation mechanism as constraints.

Regional depositional constraints \& 1D analysis made a complementary calibration tool.

Results showed a progradation over thick salt layer deposited on pre-existing relief. 
1. Introduction

1 2 Salt tectonics is one of the most complex deformation processes operating in sedimentary basins. For instance, there is 3 4no unique nor simple solution to restore complex structural sections involving salt tectonics. Most current methods of 5 6sequential restorations, however, are based on geometrical approaches imposed to the geological events. Several gross 7 8and poorly controlled simplifications are generally required to simulate such mode of deformation, not really integrated 9 10with geological process and properties, limiting applicability and effectiveness of the restoration methods. 11

12The study area of the present work in the Santos Basin was intensely deformed by salt tectonics. This passive margin 13 14basin constitutes the southernmost prolific petroleum basin of the South Atlantic Ocean which was developed over 15

16stretched continental crust in eastern offshore Brazil (Fig. 1). The deep offshore part - close to the study area - constitutes 17

18a new frontier for petroleum exploration. The wide bathymetric expression of the Santos Basin was developed over a 19

29thick salt layer, a fundamental element to the evolution of the basin history. Considering differential properties like density 21

22and compressibility between evaporites and other sediments, numerical tools are needed to control decompaction 23 24 restoration and flexural isostatic compensation.

25

26 Several authors such as Guerra (2008), Rouby et al. (1993) and Szatmari and Demercian (1993) have discussed the 27

28 basin evolution using restoration methods. Cobbold et al. (2001), Meisling et al. (2001) and other authors also interpreted

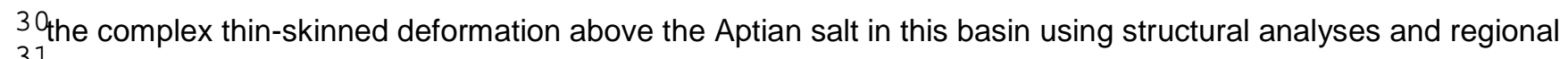

32 interpretation. More recently, a failed sea floor spreading in the southern portion, an outer high located over the São
33 ${ }_{35}^{34}$ Paulo Plateau and the overall basement compartmentalization of the basin evolution were described in several papers

36 and presentations such as Braga et al. (2003), Carminatti et al. (2008) and Scotchman et al. (2006).
37

38 In this work, a comprehensive restoration technique based on data and tools integration to minimize the strong impact of
39

$4 \Theta^{4}$ simplifications on basin evolution results is applied. The workflow also counts on geologic models in order to guide and to 42 constrain the restoration assumptions. It marks the structural modeling character of this work: not just a technique $45^{4}$ application but an idea development.

${ }_{47}^{46}$ A relatively simple 2D workflow based on classical backwards cyclic steps is carried out here: (1) isostatic flexural 48 response to unloading and decompaction; (2) modular fault-related restoration to fit a paleo-bathymetric constraint (a 50

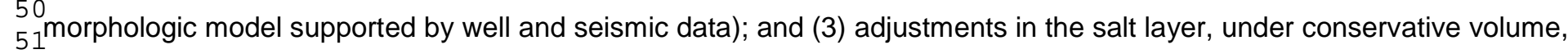
52 integrating the bathymetric and isostatic results.

54 $55^{C}$ omplementing, the $2 \mathrm{D}$ restoration is revisited through $1 \mathrm{D}$ complementary analysis, which can be used as a calibration 56 57 modeling tool, producing more consistent structural scenarios. The workflow developed in the present work intends to be 58 $59^{\text {the }}$ most rigorously integrated and interlaced as possible, marked by suitability or rightness of the tools and methods 60 61aplied. It could be applicable in other basins and complexes situations. 


\section{Geological setting}

1

2

3

4The Santos Basin constitutes a good example of continental drifting. It results from an asymmetrical partition of the 5 6Gondwanian "super-continent" whereby the Brazilian marginal basin became wider than its conjugate African basin. The 7 8Santos Basin extends over 352,000 km2 down to 3,000 m water depth. The current knowledge of its architecture comes 9 10from just over one hundred wells and numerous 2D and 3D seismic surveys. It is bounded in the northeast by the Cabo 11

12Frio High and in the southwest by the Florianópolis Platform (Fig. 1). The studied area outlined by the red polygon covers 13 $146,000 \mathrm{~km} 2$.

15

16

17

182.1 Stratigraphy

19

20

21

22The Santos Basin development can be described by successive evolutionary phases, including its pre-rift evolution, and 23

24 subsequent rifting and drifting episodes. The stratigraphic description presented herein (Fig. 2 ) is in agreement with the 25

26 general description of Carminatti et al. (2008) and the stratigraphic chart proposed by Moreira et al. (2007). A maximum 27

28 sedimentary thickness of approximately 12,000 meters was deposited in the Santos Basin depocenters (Pereira and 30Macedo, 1990).

31

${ }_{33}^{32}$ The basin opening started about $135 \mathrm{Ma}$ ago, with a 20 Ma-long period of continental breakup and rifting (Moreira et al., 342007; Pereira et al., 1986; Pereira and Feijó, 1994). A thermal intracratonic dome developed in the Late Jurassic. Its

36 collapse and coeval rifting occurred in the Early Cretaceous, leading to the opening of the South Atlantic Ocean (Williams 38 and Hubbard, 1984).

${ }_{41}^{40}$ Pre-salt sequences of syn-rift and post-rift phases are included in the Guaratiba Group. The syn-rift sequence is 42 composed of significant basaltic volcanism followed by continental sedimentation in half-grabens formed by block rotation $45^{4}$ and faulting processes. A major unconformity separates the overlying post-rift Late Aptian sequence, which was ${ }_{47}^{46}$ deposited at a time when the fault system was less active than during the deposition of older units. The Late Aptian 48 48 sequence is composed of carbonates and shales typical of a transitional environment from continental to shallow marine. 50 ${ }_{51}^{50}$ Although Moreira et al. (2007) postulated a post-rift stratigraphic position to this package, in disagreement with previous 52 authors such as Pereira and Feijo (1994), this controversy has no implication on the restoration approach carried out 54 $55^{\text {here. }}$

56 57 The Aptian Salt sequence recorded by the Ariri Formation is about $2,500 \mathrm{~m}$ thick on average. This salt formation was 58 599 uickly and unconformably deposited above the Aptian syn-rift limestones during the transition from continental to 60 $610 c e a n i c$ conditions. It extends across the West African and Brazilian continental lithospheres (Karner and Gamboa, 
2007), and was deposited under a high sedimentation rate in the order of $1 \mathrm{~km}$ over a period of 500,000 years (Dias, 1998). The age of the salt is still controversial. It has been attributed either to an early post-rift phase at the onset of 1 zoceanic spreading (Davison 2007; Gamboa et al., 2008; Henry et al., 1995; Jackson et al., 2000; Marton et al., 2000) or 3 4to a late syn-rift stage, being then the last deposits before the onset of oceanic spreading (Karner et al., 2003; lan et al., 5 62009).

7

8The drift phase is subdivided into three major sequences, i.e. the Camburi, Frade and Itamambuca groups (Fig. 2), which 9 $10 r e c o r d$ the Albian to Cenomanian sequences, an intervening Late Cretaceous progradation episode, and the Cenozoic 11 12sequence, respectively. These subsequent post-salt sequences are deformed by gravity-driven tectonics with non13 14homogeneous displacements along the basin (Assine et al., 2008), mainly due to heterogeneities of the salt thickness 15 $16 a n d$ detachment surface, as well as to a progressive tilt of the basement.

17

18The Albian to Cenomanian sequences of the Camburi Group include the first deposits clearly related to the drift evolution 19

29after deposition of the evaporites. Proximal siliciclastics, shallow-water limestones in the continental shelf, and marls and 21

22shales in the distal basin were deposited during the Albian. The overlying Cenomanian sequence records the onset of a 23 24 retrogradation pattern which accounts for the major marine transgression in the Santos Basin and culminates with the

26Turonian anoxic OAE-2 event (Arai, 1988). Most of the Late Cretaceous siliciclastic progradation sequences were 27 28 deposited in continental paleo-environments, pushing the continental shelf limits towards the most distal portions of the

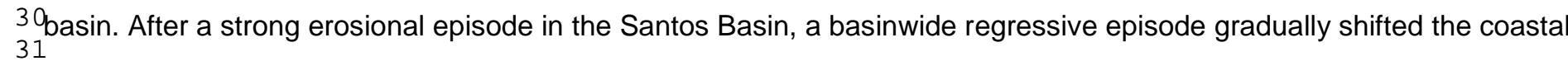
32 ine eastward for about two hundred kilometers near the Cretaceous-Cenozoic boundary, building a wide progradational 33

34 wedge. The Cenozoic sequences are marked by decreasing salt tectonics and a high frequency of sea level variations.

${ }_{37}^{36} \mathrm{An}$ important sea-level fall is associated with the Paleocene series which presents thin sedimentation in the central part of 38 the basin, probably due to reduced accommodation space and growth of salt structures (Assine et al., 2008). A new
39 .

${ }_{41}{ }_{1}$ progradation cycle during the Early Eocene accounted for the shelf break migration towards the basin, followed by 42 aggradation periods during the Late Eocene. A new transgressive trend developed above an Early Miocene unconformity, $45^{4}$ recording the largest sea-level change of the Neogene period. The Late Miocene began with a global eustatic fall ${ }_{47}^{46}$ (Gradstein et al., 2004; Moreira et al., 2007) and erosional events correlated with glaciation periods. The last and most 48 recent sediments in the Santos Basin are evolving from proximal sandstones to distal diamictites and muddy wedges. 50 ${ }_{51}^{5}$ Based on the stratigraphic chart of Moreira et al. (2007), fifteen horizons were interpreted on the 2D seismic sections. 52 These horizons have been used to build two structural sections (Fig. 3), which are about $120 \mathrm{~km}$ long and less than 20 54 $55^{\mathrm{km}}$ apart. These sections have been subsequently used as input data for the $2 \mathrm{D}$ structural restoration analysis, with 56 57 special attention to the salt tectonics. 
The São Paulo Plateau constitutes a major deepwater physiographic feature within the Santos Basin. This wide domain, 1 zalready studied by many authors (Mascle and Renard, 1976; Kumar et al., 1977; Cande and Rabinowitz, 1978; 3 4Guimarães et al., 1982; Demercian, 1996; Cobbold et al., 2001; Gomes et al., 2002; Scotchman et al., 2006, Carminatti et 5 6al., 2008), developed over an extensively stretched continental crust still attached to the Brazilian margin. The evolution 7 $80 f$ this plateau is intricately correlated to the overall dynamics of the South Atlantic margins. 9 10Ductile heterogeneities in the basement framework have controlled the evolution of the basin through time. Long NE11 12trending lineaments have been mapped onshore, and can also be clearly observed in the offshore by means of magneto13

14structural imaging, at least as far as the Cretaceous hinge line (Braga et al., 2003). Reactivations of these lineaments and 15

16coeval shear zones controlled both the formation of the coastal ranges (i.e., Serra do Mar and Serra da Mantiqueira) 17 18since the Coniacian (e.g., Almeida, 1976), and the compartmentalization of the offshore basin. 19 29nherited from the initial rifting complexity, an aborted proto-oceanic domain has been described in the southern part of 21 22the São Paulo Plateau (Carminatti et al., 2008; Gomes et al., 2002; Gomes et al., 2009; Meisling et al., 2001; Scotchman 23 24 et al., 2006). It is observed as a triangular shape of shallower bathymetry in gravity and magnetic maps (Mohriak, 2001).

26The NE-trending aborted rift propagated northward, making possible to extend laterally this feature up to coeval pre-salt 27 28 hormal faults in the proximal part of the study area (Fig. 1). Although available or published data are limited in the Santos
29 ${ }^{30} \mathrm{Basin}$, we assume that its overall crustal thinning, including this aborted rift branch, is similar to the Lavier and 31 32Manatschal's model (2006) involving an $\mathrm{H}$ block in front of a V-shaped basin (Fig. 4). This crustal thinning evolution, 33 34 which is broadly distributed in the upper crust and probably reflected basin compartmentalization by shear zones, has 35 36 geen studied in more details by Zalán et al. (2009).

${ }_{38}^{38}$ The current target for petroleum exploration, known as "the Outer High of the Santos Basin" (Gomes et al., 2002) or the

$4{ }_{41}$ SSantos External High" (Carminatti et al., 2008), is located a bit farther to the southeast of the studied area, in the 42 compressive domain. It is an important basement structure in the central part of the São Paulo Plateau. This regional high $45^{4}$ hosts the recent oil discoveries and the most important plays of the Santos Basin, with a recovery potential of 60 billion 46 parrels of oil equivalent (Carminatti et al., 2008; Gomes et al., 2009). In the Santos External High area, beyond the study 48 area, the marine sequence record is relatively thinner, with a thickness in the order of 1,000 meters. As attested by recent 50

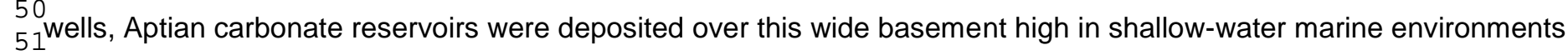
${ }_{53}^{52}$ (Carminatti et al., 2008). Beyond a shelf break, interpreted as the eastern limit of the carbonate buildup, deeper waters 54

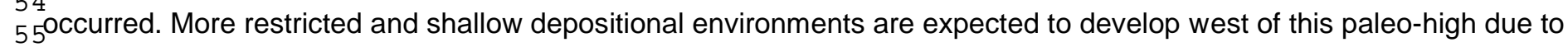
56 57 the presence of an older salt layer. The understanding of the calcareous facies succession of the pre-salt sequence of the 58 59 Santos External High is a major exploration challenge. 


\subsection{The importance of evaporites}

1 2The Santos Basin is the southernmost Atlantic basin where Aptian evaporites were deposited. Climatic conditions were 3 4favorable for salt deposition over the São Paulo Plateau and other basins to the north. These conditions were enhanced 5 6by the structural alignment of paleo-highs such as the Florianópolis Platform and the São Paulo Ridge (Fig. 1). The highs 7 8acted as an efficient barrier at the southern limits of the basin that blocked the marine water circulation derived from the 9 19proto-Atlantic Ocean extending farther south during the Aptian salt deposition. Simultaneously, the Santos External High 11

12blocked the marine waters coming from the east. A fast (ca. $0.5 \mathrm{Ma}$ ) isostatic subsidence of probably more than $1,000 \mathrm{~m}$ 13

14 was induced by the deposition of the thick salt layer. Nevertheless, the existing tectonic barriers blocked the entrance of 15

16the surrounding oceanic waters and kept the basin sufficiently closed to account for salt deposition.

17

18Evaporites can flow like a viscous material when they become loaded by sediments. The salt tectonics occurs between 19

29the Cretaceous Santos hinge line in the west and the salt pinch-out in the southeast, close to the São Paulo Ridge. They 21

22have been deformed and account for the regional spreading and gliding of the overlying sedimentary cover since the 23 24 earliest depositional stages of the Santos Basin (Demercian, 1996). The high post-Aptian accumulation rates above the

26 thick Aptian salt sequence produced a relatively shallow bathymetry over the São Paulo Plateau. During the drift phase, 27 28 both the salt and its overlying sedimentary cover were intensely deformed, resulting in a convergent radial gliding

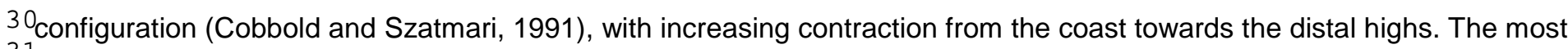
31

32 active tectonic stage was the Late Cretaceous, as a response to the loading of progradation wedges over the thick salt 33 34 layer.

36
37 38 (Mohriak and Szatmari, 2001). The classical minibasins, developing piggyback of the compressive gravity-driven domain $4{ }_{41}$ beyond this fault, seems to result from a sedimentary bypass through the slope.

${ }_{43}^{42}$ Within the São Paulo Plateau, one of the most significant preserved stratified salt columns is located over the Santos ${ }_{45}^{44}$ External High (Freitas, 2006). This package is not really autochthonous, as it has been laterally displaced above the basal ${ }_{47}^{4}$ detachment during the development of the underlying basement relief. More rugged features observed on section A-A' ${ }_{49}^{4}$ can be related to the preexisting structural framework, differentiated between the sections A-A' and B-B' (Fig. 3). 50

51

52

$53^{3}$. Methods

54

55

56

57 The restoration procedure presented here is based on the following backwards successive steps: (1) sediments removal 58 5 gand decompaction with isostatic flexural compensation; (2) fault-related and salt movement restoration fitting the paleo60 61 geometry to a reference target; (3) final paleo-bathymetric adjustments. Compared with other restoration methods (e.g. 
Rowan, 1993), this restoration is a simplified derivation which simultaneously considers a flexural isostatic compensation and a vertical decompaction procedure. In addition, it does not consider any direct control, data about eustasy or thermal 1 cooling. All effects of these processes are compensated in the final paleo-bathymetric calibration. Fault-related and salt 3 4movement deformations are restored in traditional handmade transformations considering a conservative mass balance 5 for the sedimentary layers, including the ductile salt, and a defined paleo-geometry (shelf-slope-rise) with a coherent 7 8structural style of salt deformation. This restoration solution method is performed on RECON-MS, a Petrobras in-house 9 10 software.

11

12Backstripping with flexural isostatic compensation - Due to compaction laws, the layer decompaction solution with 13

14isostatic correction requires a detailed facies definition along the entire section. Only the salt layer is considered not 15

16 compressible during the decompaction step. Once the uppermost sedimentary layer is removed, the decompaction of the 17

18underlying layers due to the removal of its overburden is a discretized calculation along the section. All the remaining 19 20 decompacted units are referenced to the base of the removed unit. Once the decompaction is done, isostatic 21

22 compensation with a crustal flexural deformation component is calculated. This procedure can be found (including 23

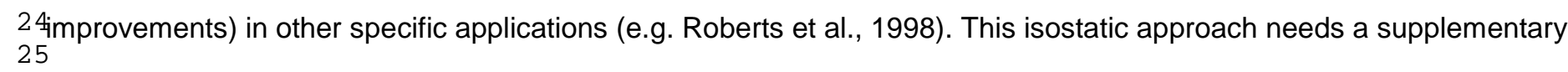

26 paleobathymetry calibration data to fit the real equilibrium. The magnitude of isostatic flexural deformation depends on the 27

28 applied sedimentary load as well as on the flexural properties of the crust that undergoes the deformation. An unloading
29

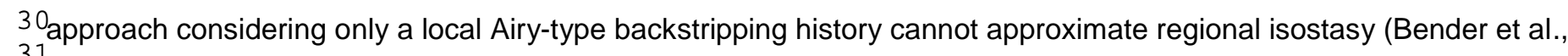
321989; Karner, 1982; Roberts et al., 1998; Watts et al., 1982).

33

${ }_{35}^{34}$ The sections length (around $120 \mathrm{~km}$ ) does not represent the entire sedimentary basin load (which extends over more

36
37 han $400 \mathrm{~km}$ beyond the study area), thus producing a narrower isostatic unloading than it really should be. The post-salt 38 sequence becomes progressively shortened in the study area during the sequential restoration of the salt gravitational

${ }_{41}^{4}$ gliding, which means a similar loss in the representativity of the load. An additional sedimentary load is required in the 42 sections in order to compensate the loading representativity and further border effects. It is needed to simulate the $45^{4}$ regional extent of the basin as well as to restore in the initial sections the missing portions of the sedimentary cover and 46 of the initial salt layer, which have been subsequently translated outside of the model. The lateral continuity of the Aptian 48 evaporitic sequence (more than two thousand meters thick) towards the Santos External High (Carminatti et al., 2008; ${ }_{51}^{50}$ Gomes et al., 2009) (Fig. 5) make this lateral insertion of sedimentary section a reasonable assumption.

52

53

54

$55^{3.1 . ~ M o d u l a r ~ r e s t o r a t i o n ~}$

56

57

58

59 To restore the original features of each section, the applied algorithms retain length or area of layers respecting the 60

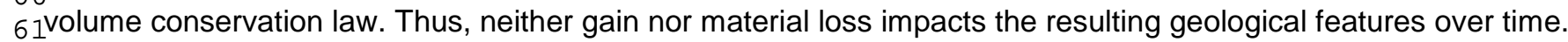


Considering dominant ductile deformation for the salt layer and brittle deformation for other sediments, whenever needed, the section has been subdivided every restoration cycle into minor individual modules with a similar deformation process. 1 2These modules are limited by well defined geological elements such as stratigraphic contacts, salt diapirs borders, sea 3 4floor and/or normal faults. Each module is restored by geometrical transformations in order to better fit the target 5 6geometry (reference paleo-bathymetry) and lateral module boundaries (faults, diapirs or section borders). We have used 7 8here the simplest methods to obtain simple restoration solutions. The solution implemented for the simple shear 9 10transformations in the software is able to preserve the modules' areas on the 2D restoration results. These shear 11

12transformations were used to restore brittle modules in the extensional deformation domain and also in less deformed 13

14situations of the distal domain. Flexural unfolding transformations preserving length on the template bed direction and 15

16parallel to the unfolding axes were preferentially used to restore most of the folded minibasins modules. Considering that 17

18the major deformation is concentrated close to the faults and diapirs flanks, sometimes partial restoration steps were 19

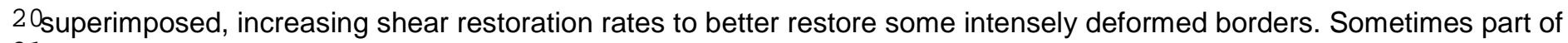
21

22the salt diapir was included in the module to smooth the rugged fault or diapir geometries. All these operations could be 23 24 similarly reproduced with any commercial restoration software.

26 In contrast with other brittle sedimentary rocks, the ductile rheology of the salt layer was treated by free adjustment to 27 28 other restored modules. The salt layer thickness was modified to conform the differential deformation between its 30 overlying and underlying layers. The degree of freedom of this salt operation was established by structural coherence, a 32 factor discussed further below, always respecting the limits of the restored overburden. A constant amount of salt is an 33 34 approximate hypothesis applied only under this overburden. Along the whole section, it is not a reliable hypothesis for the

36 three-dimensional gravitational gliding of the study area. The lateral "void" created due to the lateral shortening of the 38 restored extensional domain is filled as explained before.

${ }_{47}^{46}$ The 2D restoration approach requires paleo-bathymetric profiles at each incremental step to which the basin-driving 48 subsidence should be adjusted. The Santos Basin is characterized by a wide and shallow continental margin made up of 50

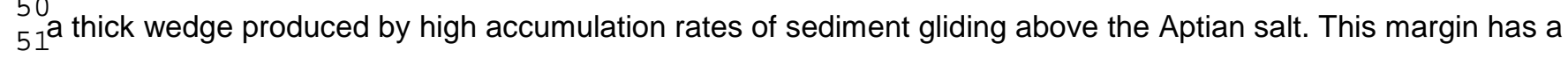
52 particular development in the basin - $700 \mathrm{~km}$ offshore - decreasing the brittle sedimentary thickness over distal portions 54

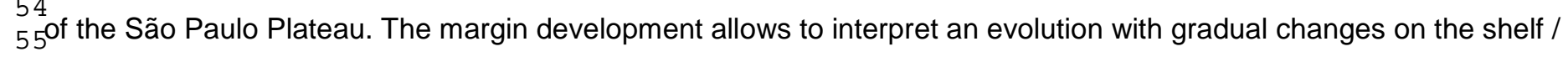
56 57 slope / rise geometry, always controlled by highs at the distal positions.

58 59 The shelf / slope / rise limits can be recognized by their general characteristics. The continental shelf domain is an 60

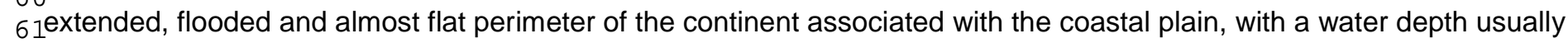


limited to $200 \mathrm{~m}$ (Pinet, 1996). In the case of the Santos Basin continental shelf, it is exceptionally wide (in the order of $200 \mathrm{~km}$ ). The shelf ends when the slope gradient abruptly changes at a point called shelf break. This point was quite easy 1 2to interpret in the seismic sections for the different post-salt interpreted horizons. Beyond this gradient break, the average 3 4gradient of the continental slope is $3^{\circ}$, with a maximum value of $10^{\circ}$ (Gross, 1972). The transition to the continental rise is 5 6marked by another gradient change at the foot of the continental slope, beyond which a sedimentary pile was still 7 8depositing. The topographic gradient of the continental rise is intermediate between the previous domains, in the order of 9

$100.5-1^{\circ}$. In the Santos Basin, it merges with the deeper oceanic part of the abyssal plain through the São Paulo Ridge 11 12topography.

13

14The shelf break and the foot of the continental slope were interpreted for each different horizon on the $2 \mathrm{D}$ seismic data in 15

16the study area (Fig. 6), as well as their general paleo-geometry position through time. These points provide key 17

18references for the shelf / slope / rise target geometry during the restoration of modules. The final geometry was ultimately 19 20 calibrated by the available paleo-environment data from wells. Additional uncertainties can be considered about the 21

22 proximity and possible similarity of the shelf break point with the axis of the Cabo Frio roll-over fault. The basal points 23

24 called foot of the continental slope are always located on the hangingwall of the Cabo Frio Fault in the study area. 25

26 Every individual decompacted module has been restored to fit the target geometry of the restoration timing as a first 27

28 approximation. Some difficulties arise to adjust the isostatically decompacted layers to this target geometry. They will be

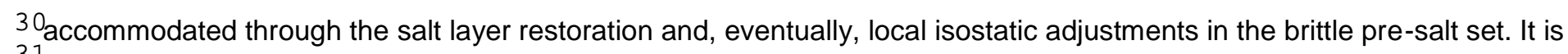
31

32 important to remember that both thermal-subsidence and eustatic processes are not considered in the calculations, but 33

34 they will be compensated by the paleo-bathymetric calibration.

36

37

383

40

41

42 The most important criterion for the restoration concerns the structural consistency. The structural evolution from salt

${ }_{45}^{4}$ deposition to present time results from gravity gliding and progradation above a thick and ductile salt layer. The

46

46 extensional features occur in the proximal parts of the sections, i.e. in the platform and upper slope domains. ${ }_{49}^{48}$ Compressive gravity-driven structures and the minibasins development are restricted beyond the toe of the continental 50 ${ }_{51}^{50}$ slope, where relatively thinner post-salt layers are observed. During the gravity gliding deformation, the thick salt layer 52 53 gradually becomes more deformed.

54

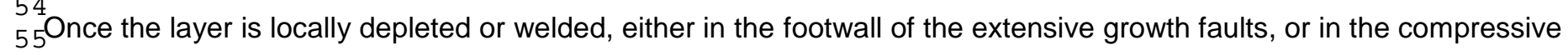
56 57 domain below some minibasins, both the overburden and salt thicknesses must be consistent with the paleo-bathymetry. 58 59 This must be checked every restored cycle. If erosion features observed on the slope domain are interpreted as a local 60 61 restriction for accommodation and/or sediment bypass, no major thickness variation would be expected at these positions 
in the salt layer restoration. On the other hand, if a thicker layer is deposited after salt withdrawal, either due to local collapse or gravity slide, this shift must also be consistent with the paleo-bathymetry in the salt layer restoration. 1

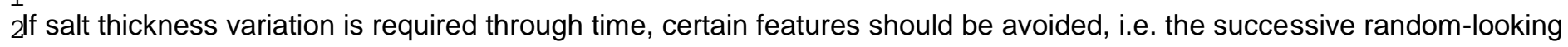
3 4opening and closing of salt windows as well the random increase and decrease of the salt thickness. In all these 5 6situations, the local subsidence rates applied to brittle layers and deformation rates of the underlying ductile salt layer 7 8should be consistent with the bathymetry variation.

9

10Figure 7 shows a detailed restoration example of the cyclic applied methodology. These restoration steps include: 11

12) The initial (present day) condition of the section A-A';

13

14II) The decompaction of the most recent layer with flexural isostatic compensation; 15

16III) First paleo-bathymetric approximation, indicated by the dashed line based, in this case, on the present day bathymetry 17

18 which is represented by the blue line. Both lines were superposed on the top of the decoupled post-salt package. This set 19

$2 \mathrm{Gis}_{\text {s }}$ decoupled of the pre-salt package, once the salt layer had been suppressed. Small circles show two salt windows that 21

22should be preserved;

23

$24 \mathrm{IV}$ ) Adjustments of the post-salt package to the top target dashed line by geometric operations opening locally a larger 25

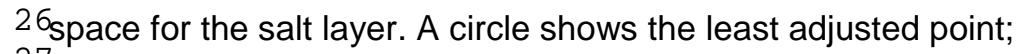

27 $28 \mathrm{~V}$ ) Final adjustments required to better replace the initial amount of salt below the post-salt package. This step leads to a
29

$30_{\text {completed restoration cycle. }}$

31

32

33

344 . Restoration and discussion

35

36

37

${ }_{39}^{38}$ Fourteen different restoration outcomes are presented as restoration results for the geological evolution of fifteen $41^{4}$ interpreted horizons in the two sections, $A-A^{\prime}$ and $B-B^{\prime}$. These results were obtained following the procedure already ${ }_{43}^{4}$ described above. The older three restoration outcomes are related to deformation of the pre-salt sequence when brittle 44
45 tectonics was prevalent. They are strongly different from the other eleven restoration cycles which are recording the ${ }_{47}^{46}$ effects of thermal subsidence and ductile salt deformation. The pre-salt sequence is the first of five major sequences 48 considered in the structural evolution to account for the different observed architectures. The subdivision of the post-salt 50

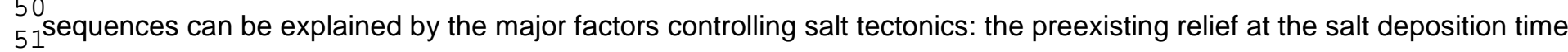
52 $53^{\text {and }}$ the sedimentation rate.

54 55 They provide different conditions of instability for the gravitational gliding and also different ratios of thickness between 56 5 the salt layer and its overburden through time. These various aspects of salt tectonics have been already well discussed 58 5 gby several authors (e.g., Cobbold and Szatmari, 1991; Weijermars et al., 1993; Lerche and Petersen, 1995; Garcia, 1999; 60 61 Mohriak and Szatmari, 2001; Hudec et al., 2009). 
The five sequences are described below.

1

24.1. Pre-salt sequence

3

4

5

6 The quality of the subsalt seismic imagery is not good enough here to solve uncertainties related to the pre-salt layers. In 7

8general, the tilted blocks involving the basement and synrift strata beneath the base of the salt were defined only by few 9

1 đfaults without any good definition of the dipping attitude of infra-salt series (Fig. 8).

11

12The observed unconformities are not well mapped continuously either, and no data about the target relief for these 13

14sequences are available. The restoration for these sequences was strongly marked by rotation and an important 15

16 extension is observed in the proximal deep basement domain. This latter feature is consistent with the hypothesis of a 17

18northward lateral prolongation of the brittle normal structures described earlier farther south in the failed spreading centre 19

20 (Fig. 1). It seems also possible that this structural low was already formed before the salt deposition time. The geometry 21

22 at the restored scenario of the pre-salt sequence top predates the conditions to the salt deposition. However, the lack of 23

24 bathymetric data prevents any secure calibration and therefore, this geometry remains quite speculative, resulting only 25

26 from the isostatic and structural adjustments applied during the restoration. Ultimately, the pre-Aptian basement 27

28 architecture is assumed here to have been less deformed than the present-day architecture of the pre-salt layers derived
29 30 from the interpretation of seismic images.

31

32

33

344.2. The Aptian Salt sequence

35

36

37

${ }_{39}^{38}$ The salt layer glided progressively toward the deeper centre of the basin, due to gravitational instabilities (Fig. 9). The

$41^{4}$ ight pink portion of the salt layer represents the amount its restored movement. In the study area, a very heterogeneous ${ }_{43}^{42}$ salt layer presents different average thickness in each section: it is around 1,600 m-thick in section A-A' and only about $45^{400}$ m-thick in section B-B'. A large amount of salt was pushed toward the distal portions of the basin, outside of the study 46 47 48 $49^{c o m p e n s a t i o n ~ r e s p o n s e, ~ p a r t ~ o f ~ t h e ~ b a s e m e n t ~ t i l t i n g ~ w a s ~ m o d i f i e d ~ i n ~ o r d e r ~ t o ~ g e n e r a t e ~ e n o u g h ~ a c c o m o d a t i o n ~ s p a c e ~ a n d ~}$ 50 $51^{\text {to }}$ restore a more homogeneous salt layer over the preexisting rift geometry. The resulting salt layer thickness is about $52,2,800 \mathrm{~m}$ for section A-A' and about 1,200 m for B-B'. These differences were due the initial rifting geometry but also due 54 $55^{\text {to }}$ isostatic differential effects in both sections. A very smoothed yet not flat geometry was proposed here for the top of the 56 57 restored salt layer at its deposition time. Considering the available seismic data and the significant superimposing effects 58 590 f continuous salt deformation, it was not possible to interpret any structural feature deforming the Aptian salt before 60 61 deposition of the clastic and carbonate overburden units. 


\subsection{Albian to Cenomanian sequences}

1

2

3

4The first post-salt sequences include the deposition of Albian carbonates and part of the Late Cretaceous marine 5 6siliciclastics. These sequences involve several fault-separated modules with gaps of several kilometers in both sections, 7 8including some uncertainty about their extent in some intermediate modules (Fig. 10). The simply deformed modules 9 10document the large magnitude of raft tectonics operating at the onset of halokinesis. The great salt volume associated 11

12with a still thin overburden favours a fast gravitational gliding of the latter, resulting in lateral gaps where the Albian13

14Cenomanian cover was progressively displaced. Different sedimentation domains and paleo-environments were linked 15

16with the shelf / slope / rise geometries, respectively. A relatively thick salt layer is interpreted in the shelf / slope portions 17

18whereas thin and folded sediments are observed in the rise domain.

19

20The thickness variations interpreted in the seismic data for the Albian and Cenomanian layers show a thick proximal 21

22portion developed in continental shelf and slope domains. An underlying thick salt layer provides the initial minimum basin 23

24 amplitude to accommodate the carbonate shelf development. Thin and folded distal Albian carbonates interpreted as 25

26 continental rise deposits are clearly restored in their initial folding stage and reconnected at their correct paleo27 28 bathymetric position (Fig. 11). In the next steps, still before the development of the classical minibasins, they were
29

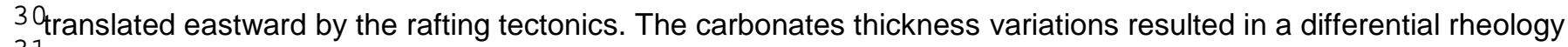
31

32pattern, which controlled the Cabo Frio Fault development. Restoration results suggest that the Cabo Frio Fault evolution 34 is correlated with the progradation of the thicker overburden and the squeezing of the salt towards the thinner portion of $36^{4}$ he basin located at the local structural high currently observed in the middle of the sections.

$41^{4.4}$ Late Cretaceous progradation sequences

42

43

${ }_{45}^{44}$ During the massive progradation of the Upper Cretaceous, the salt movement has built multiple overburden ${ }_{47}^{46}$ compartments limited by faults or salt structures (Fig. 12). The proximal area is initially characterized by a thicker post-salt 48 package, already compartmented by diapirs with antithetic tendency in a restricted area behind the foot of the slope. The 50 51 slope advances as a consequence of the progradation event and seems to control the Cabo Frio Fault development since 52 its onset. Structural and thickness differences among these Late Cretaceous restored outcomes are observed in both 54

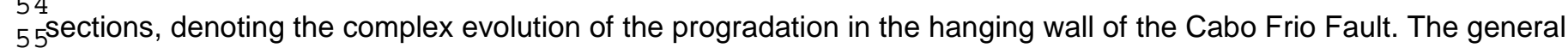
56

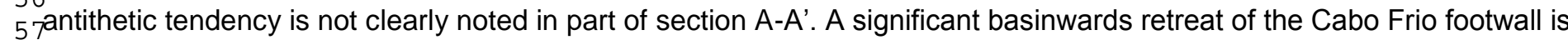
58

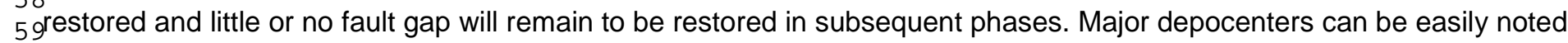
60 61 beyond the continental shelf. The minibasins became more developed during this progradation. Such regional shift of the 
sedimentation pattern was already described by Assine et al. (2008). The location of these depocenters is probably controlled by a bypass through a continental shelf blocking against the local structural high, and by a local ramp 1 zadjustment in the Cabo Frio Fault. Initial salt windows are formed beneath locally thick post-salt depocenters. 3 4

5

64.5. Tertiary sequences

7

8

9

10The top and most recent layers are the least deformed (Fig. 13). They present limited deformation compared to the final 11

12stages of salt tectonics. These layers were deposited under moderate sedimentation rates, not enough to induce 13

14 significant thickness variation or salt deformation. The post-salt overburden is already very thick and there are many 15

16welding points and salt windows to block the salt gliding.

17

18The Cenozoic evolution was the easiest to restore within the study area. However, the isostatic response shows very 19

2 Gimited accommodation space near the slope domain, close to the salt growing structures where local thickness variation 21

22 and small erosional traces are observed in seismic data (Fig. 14, detail 1). If these constraints point uncertainties about 23

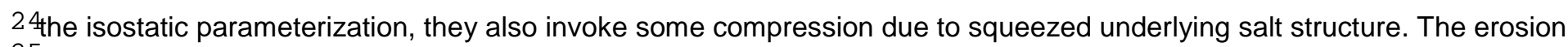
25

26 features on the Miocene horizon produce diagnostic roughness on the horizon surfaces that can be smoothed in order not 27 28 to transfer them downwards. Ongoing activity of fold growth associated with the salt diapirism at the borders of the
29

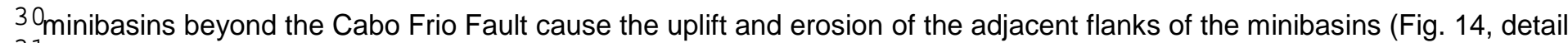
31 32)

${ }_{41}^{40} \mathrm{Applied}$ as lower boundary conditions to the sedimentary layers below the salt during restoration, the calculations for the 42 flexural isostatic compensation consider the entire loads applied to the mantle by the basin infill and crust. A potential
43 ${ }_{45}^{4}$ crustal weakness in the Santos Basin was considered with values of $5 \mathrm{~km}$ for the effective elastic thickness and 2.78 ${ }_{4}^{46} \mathrm{~g} / \mathrm{cm} 3$ for crustal density along the whole section and during all the geologic time. The crustal thinning can be estimated 48 by horizontal stretching or synrift sedimentary loading as in the models of McKenzie (1978), Wernicke (1981), or by $5{ }_{51}$ formation of weak ductile shear zones as in the model of Lavier and Manatschal (2006), but no specific study has been 52 ${ }_{53}^{5}$ done to measure these parameters that were arbitrarily assigned. These are sensitive parameters. Using them, it is 54

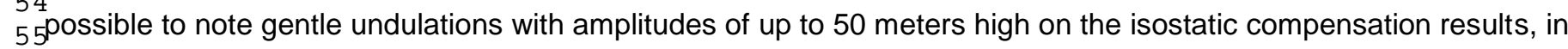
56 57 phase with the paleo-environmental adjustments required to restore the sections. On the other hand, if we use values of 58 $5920 \mathrm{~km}$ for elastic thickness and $3.33 \mathrm{~g} / \mathrm{cm} 3$ for crust density, for example, then the flexural isostatic compensation for the $6 \odot$ 61 removal of the upper layer (the most recent sediments) would be $18 \%$ deeper. In contrast, the heterogeneities of diapirs, 
minibasins and growth faults with a wavelength of a few tens of kilometers would not cause any noticeable differential isostasy at the scale of the restored sections. One simplified and homogeneous crust with a single elastic thickness 1 2through space and time can also be unrealistic given the basement rheological heterogeneities. Moreover, the crustal 3 4elastic thickness could vary with both its physical integrity and with the thermal regime to which it is submitted. Difficulties 5 Go set the restored scenario into the bathymetric limits established by data and the isostatic response can be observed on 7 8the results, mainly in restoration cycles comprised between Eocene to recent times (Figs. 13 and 14). According to the 9 10restoration progression in the earlier stages (from Albian to Maastrichtian), even if the salt tectonic is more intense, a 11 12thicker salt layer gives more freedom to restore and adjust the restored paleo-bathymetric model. An important limitation 13

14 of the restoration tool is the fact that no isostatic effect for the repositioned restored sedimentary masses is recalculated. 15

16This can be observed in the isostatic magnitude of the restored Cenomanian outcome for section B-B' (Fig. 10) where the 17

18 isostatic response to the removal of the first progradational deposits (Fig. 12, dark orange layer) is noted in the basal 19 $20 \mathrm{geometry}$ of the restored Cenomanian outcome, without any recalculated effect of the thicker restored salt layer. The 21

22 more layers are interpreted or interpolated in a section, the more this isostatic deviation could be minimized, i.e., shorter 23

24 time intervals from one restoration phase to the other represent more frequent repositioning and smaller lateral transfers 25

26 f restored masses. However, the effect remains in the accumulated result.

27

28

29

$30_{4.7 .}$. Bathymetry

31

32

33

${ }_{35}^{34}$ Applied as upper boundary condition to every post-Aptian restoration cycles, the bathymetry model proposes target 36 geometries with low resolution (according to the available data). The uncertainties in the bathymetry model are 38 represented by large intervals of time and wide ranges of water depth (Fig. 15). In the deeper portions and for several $4{ }_{41}$ restoration cycles which have no data available, the bathymetric model was freely extrapolated. A critical point was found 42 at the evaporites deposition time. The model assumes a preexisting low, not invaded by oceanic waters, since the 44 isostatic effect produced by the thick salt layer requires additional space so that its fast and continued deposition does not 46 ${ }_{47}^{46}$ Create positive relief (there is no salt deposition on mountains). For the older units, deformed under a rifting tectonic 48 regime, there are no paleo-environmental data for calibration and irregular reliefs were produced by the restored rotated

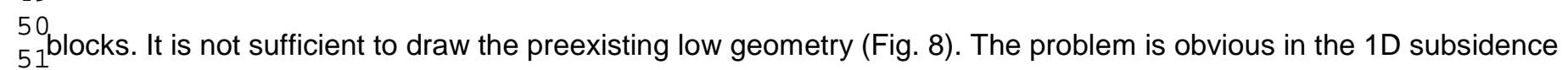
52 geohistory graphics discussed ahead. 
Applied throughout the section to all restored cycles after salt deposition, a solution to the lateral movement of masses due to the salt gliding takes into account different limitations for bathymetry and isostasy in each situation. This 1 zhandmade solution aims at a structural coherency through time so that there are no observed alternations of thickness or 3 4 controversial structural inversions. Intense salt deformation starts from an initial scenario with more homogeneous salt 5 Ghickness, with longer wavelength for domes and diapirs while overlapping clastic sediments partially expel the underlying 7 8salt. All positive reliefs of salt were cut and compensated in the restored salt layer. Situations where salt is locally 9 10cropping out at the seabed are consistent with clastic sediments flanking laterally the structures which are involved in 11 12progressive unconformity and differential compaction processes, and are covered by a cap rock at the top (Fig. 16). 13

14The partial accounting of the evaporite layer for each structure is compatible with the deformation history. A larger initial 15

16volume of salt in the proximal part of the section migrates progressively towards the structural high in the section center, 17

18pushing massive clastic material to more distal portions. The difference of salt material between the two sections results 19

$29_{\mathrm{in}}$ a different structural restoration for each one. The salt laterally flowing out in each section is not proportional to the salt 21

22 existing at present day in the section. It increases from $75 \%$ in the A-A' section to $160 \%$ in the B-B' section. Whereas the 23

24 amount of salt is 2.4 times greater at the present day in the A-A' section than in the B-B' section, this relationship is only 25

261.6 times for the Aptian restored outcome, at the initial deformation stage of salt sequence. These variations suggest that 27

28 the distribution of salt was spatially more homogeneously in the past and the salt layer was more efficiently pushed away $39_{\text {in }}$ the B-B' section. The restoration solution considered no synchronism between the extension processes in the salt 31

32 gravity-driven deformation domain and those deforming the layers below the salt. The accumulated extension represents 34 an increase of almost $60 \%$ for the section in the package deformed by salt tectonics in the study area. The accumulated

36
37 38 different below and above the ductile salt layer in the study area. They were independent. The salt layer worked as a full

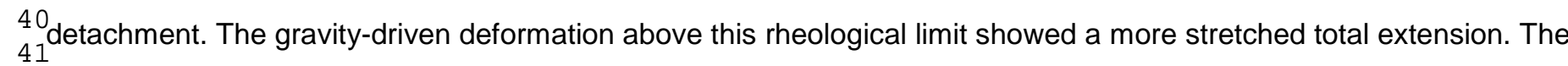
42 results for the brittle deformation domain below this limit are consistent with the assumption of Moreira et al. (2007). For 44
45 these authors, the master faults of the rift phase ceased their activities or suffered rare reactivations after the deposition 46 of Barra Velha Formation (Fig. 2) and this deformation, almost totally produced before the salt deposition, was fully 48

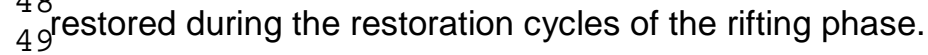

50

51

52

53 . 4 . Geohistory based on $1 \mathrm{D}$ modelling 54

55

56 57 Gravitational mass gliding is not usually considered in basin modelling studies, which rather focus on thermal or 58 59 subsidence aspects. Subsidence history graphs based on wells or pseudo-wells allow simple and useful evolutionary 60 $61^{1}$ analysis where some implications and consequences of a large horizontal gravitational mass movement for the petroleum 
systems could be observed. In many previous 1D studies, phenomena related to salt deformation were solved by the simple salt thickness variation (diapirism). The restoration results to the spatial deformation of the structures through time 1 2gave new dimensions for 1D modelling studies, with new approaches for time and space. The points of a fictive vertical 3 4line composing a pseudo-well in the section at present day came from upstream positions in the former restoration 5 6outcomes, due to a differential motion controlled by the cumulative amounts of extension through time. On the other 7 8hand, a fictive vertical window in the same section position shows how the overburden that glides to downstream 9 10situations is progressively replaced by the former neighboring overburden. For instance, the initial overburden that was 11 12deposited above this fictive point in Albian times has been moved away, being now replaced by another segment of the 13 140verburden which was deposited farther west, due to the ongoing gravitational gliding. These approaches can be 15

16differentially applied to calibrate thermal models based, for example, on vitrinite reflectance data from younger layers and 17

18 to analyze the evolution of a source rock deposited below the salt layer. Built from restored sections results, the 19 20 subsidence and overburden historical graphs here presented (Fig. 17) replace the traditional image of layers under 21

22 ncreasing compaction by layers under tectonic movement. The relevance of the results on thermal effects that can be 23 24 analyzed with this approach depends on the magnitude of the accumulated lateral movement that the system has 25

26 undergone. As most of the thermal data are obtained in more recent layers and their lateral shifting due to the 27 28 gravitational gliding is not so large, no great differences are observed compared to a traditional approach. However, for

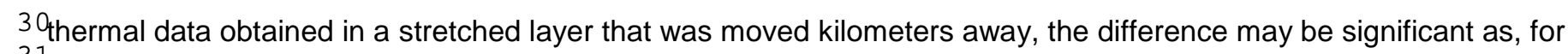
31 32 example, when the layer is moved from a diapir flank to an overburden position of a source rock kitchen. These graphs
33 34 35

37 reference evolutionary scenario to constraint various parameters such as bathymetry and isostasy. Even if a bathymetry 38 history was designed as a coherent evolutionary model, some imperfections can be observed through time in a few ${ }_{41}^{40}$ restoration outcomes, resulting from handcraft restorations of the modules targeting low-resolution bathymetric data. 42 Without any control for the restoration of the older units, a dry depression is postulated to the pre-salt sequence, prior to ${ }_{45}^{44}$ the deposition of a thick salt layer, especially when the salt isostatic response is too small to prevent the creation of a 46 positive relief of salt above sea level. Following this transitional isostatic jump provided by salt deposition, a shallow 48 49 marine deposition took place during the Albian and gradually changed to a scenario of maximum water depth observed at 50 $51^{50}$ the Turonian. This trend toward restoration cycles involving even deeper waters is reversed by a progradational clastic 52 sedimentation in the Late Cretaceous.

54 ${ }_{55}$ Since then and until the present day, an evolutionary change accounted for the progressive building of the current basin 56 57 configuration, during a period characterized by slower salt tectonics. The initial restored salt layer is very thick in all 58 599 raphs. It allows smoothed bathymetry adjustments to all isostatic calculations, considering the salt layer as a 60

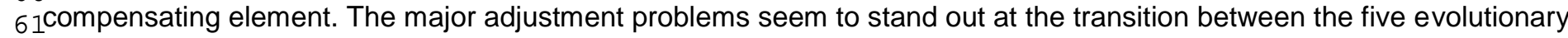


sequences described before. Even if there is uncertainty about the initial thickness of salt, the restored salt volume in the results seems to be excessive. Assuming a large availability of salt, these 1D graphs suggest that most of the 1 zaccommodation space created during the salt tectonics is due to the lateral expulsion of salt under the continuous burial 3 4of the Santos Basin, providing a good summary of the progradation history (Fig. 17). Pseudo-well 1B shows significant 5 Gproximal sedimentation easily accommodated in Albian to Cenomanian times; whereas pseudo-well 2A shows Late 7 8Cretaceous progradation and pseudo-well 4A shows Cenozoic representative thickness. The clastic progradation from 9

10Late Cretaceous imposes greater deformation on the salt layer. Pseudo-wells 1B, 2A and 4A in Figure 17 are positioned 11

12in post-salt depocenters (salt windows), from where thick salt layers had been gradually squeezed at different times 13

14(Turonian for pseudo-well 1B, top Cretaceous for pseudo-well 2A and Miocene for pseudo-well 4A). In contrast, pseudo15

16well 3B is positioned above a thick salt wall close to the Cabo Frio Fault. This pseudo-well shows the Late Cretaceous 17

18evolution of a minibasin, coeval with a progradation event. It also shows that the salt layer underwent a relatively 19

20continuous thickening during its lateral gliding away from more proximal areas. Major problems found in these graphs are 21

224inked to periods with the higher sedimentation rates: the more intense is the deformation under higher clastic supply, the 23

24 greater are the difficulties to set bathymetry and isostasy for the restored timing. These graphs represent a good quality

26 control for the restoration process itself. Because the entire restoration process has some intervention from the 27 28 interpreter, several deviations could be unintentionally introduced in the meantime. The simultaneous visualisation of

$30^{\text {these }} 1 \mathrm{D}$ graphs can be a useful tool to identify the critical points and to get better results.

32

33

345. Conclusions

36

37

${ }_{39}^{38}$ The approach integrating structural restoration tools with isostatic control and paleo bathymetric model is very important

$4{ }_{41}$ to the obtained results. The configuration of the transition from rifting to drifting phases is a consequence of the salt 42 tectonics backward restoration. ${ }_{45}^{44}$ Aparently, the results help to characterize the general complex framework for the geometry of the salt depositional 46 environment, but they are not conclusive to provide insights about the pre-existing rifting depositional domains and facies. ${ }_{49}^{48}$ For the post-salt sequences, deformed by halokinesis, the brittle clastic package developed early in the proximal domains 50

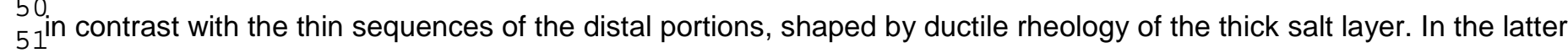
52 domain, these thin sequences either behave as small rafts during early extension or develop a subsequent and 54

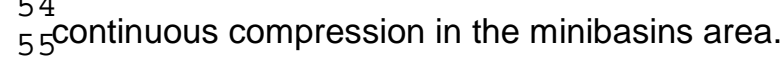

56 $57 \mathrm{~A}$ conservative salt volume is not a realistic constraint in the study area. A first approximation was provided by the $2 \mathrm{D}$ 58

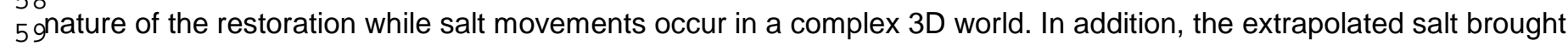
60

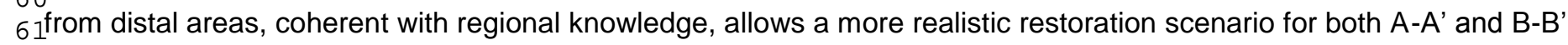


geological sections. This approach allowed a decoupled restoration where bathymetry controls the sequence above the salt, isostasy controls the package below the salt and the ductile salt layer works as an element of local compensation. 1 2Paleo-bathymetry data and flexural isostasy calculations provide guidelines to restore independent packages above and 3 4below the ductile salt layer. Simplified and arbitrary parameters assumed in the restoration processes did not detract from 5 Ghe methodology approach. Recognized problems were produced by handmade interventions during the simple shear 7 8and flexural slip operations and also by the lack of isostatic compensation of the lateral movement of the restored 9 10modules.

11

12Geohistory 1D analysis established from 2D section restoration results are complementary tools to improve the whole 2D 13

14palinspastic process. Inconsistencies produced during restoration steps can be easily observed in these graphs and use 15

16again as a new input for further optimization loops. They allow a consistent evaluation of the local bathymetry variation 17

18through time. The 1D subsidence graphs confirm that the sedimentary evolution in the study area results from a continuos 19

20 sedimentary progradation. They illustrate salt welding first in proximal portions and, consequently, salt windows gradually 21

22 opening over time from these regions to the most distal ones. They also provide a different approach based on the lateral 23

24 mass movement for $1 \mathrm{D}$ thermal modelling.

${ }_{27}^{26}$ The simplified 2D restoration approach with independent and interactive bathymetry, isostasy and modules

28

290peration controls here presented could provide easy guidelines for new 3D restoration solutions and 30

$31_{\text {developments. }}$

32

33

34

35

36

37

38

39

40

41

42

43

44

45

46

47

48

49

50

51

52

53 


\section{Acknowledgments}

1 2Fist of all, we would like to thank Petrobras for all support during the present research. We also express our 3 ${ }_{5}^{4}$ gratitude to Sylvia Anjos, François Roure, Henrique Penteado, Luiz Antonio Freitas and Cláudia Lima who 6

7made important contributions to this paper. Our thanks to all the Petrobras E\&P petroleum systems geologists, 8

9 the IFP Energies Nouvelles researchers and the Tecgraf IT support team. This paper would not have been 11

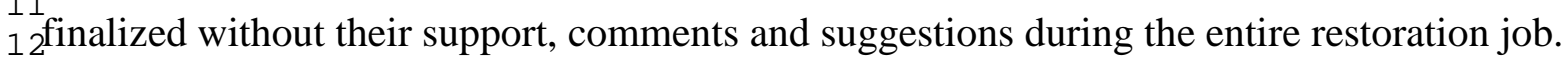
13 14 


\section{References}

\section{Click here to view linked References}

\section{References}

1 2Almeida, F.F.M., 1976. The system of continental rift bordering the Santos Basin, Brazil. Anais Academia Brasileira 3 4Ciencias, 48 (suppl.), 15-26.

5 6Assine, M.L., Correa, F.S., Chang, H.K., 2008. Migration depocenters in the Santos Basin: importance for hydrocarbon 7 8exploration (Migração de depocentros na Bacia de Santos: importância na exploração de hidrocarbonetos). Revista 9 10Brasileira de Geociências 28, (2) supplement, 111-127. 11 12Arai M., 1988. Geochemical reconnaissance of the Mid-Cretaceous anoxic event in the Santos Basin, Brazil. Revista 13 14Brasileira de Geociências 18, 273-282.

15

16Bender, A.A., Mello, U.T., Chang, H.K., 1989. Bidimensional reconstitution of the geologic history of sedimentary basins: 17 18theory and its application in the Campos Basin (Reconstituição bidimensional da história geológica de bacias 19 20sedimentares: teoria e uma aplicação na bacia de Campos). Boletim de Geociências da Petrobras 3 (1/2), 67-85. 21 22Braga, L.F.S., Costa, C.M., Gama, F., Fontoura, C., Cunha, A.S., Dourado, F., Correa, F.S., 2003. Magneto-Structural 23 24 maging (MSI) and Regional Basement of the Santos Basin, Brazil. International Congress of The Brazilian Geophysical
25 26 Society, 8, Rio de Janeiro, SBGf. CD-ROM. 4 p. 27 ${ }_{29}^{28}$ Cande, S.C., Rabinowitz, P.D., 1978. Mesozoic seafloor spreading bordering conjugate continental margins of Angola

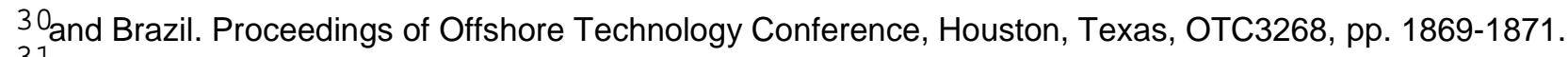
${ }_{33}^{32}$ Carminatti, M., Wolff, B., Gamboa, L.A.P., 2008. New exploratory frontiers in Brazil. 19th World Petroleum Congress, 34 Madrid, Spain, WPC proceedings. ${ }_{37}^{36}$ Cobbold, P.R., Szatmari, P., 1991. Radial gravitational gliding on passive margins. Tectonophysics 188, 249-289. ${ }_{39}^{38}$ Cobbold, P.R, Meisling, K.E., Mount, V.S., 2001. Reativation of an obliquely rifted margin, Campos and Santos Basin, ${ }_{41}^{40}$ Southeastern Brazil. Am. Assoc. Petrol. Geol. Bull. 85, (11), 1925-1944.

${ }_{43}^{42}$ Davison, I., 2007. Geology and tectonics of the South Atlantic Brazilian salt basins, in: Ries, A.C., Butler, R.W.H., ${ }_{45}^{44}$ Graham, R.H. (Eds.), Deformation of the continental crust: The legacy of Mike Coward. Geological Society, London, ${ }_{47}^{46}$ Special Publications, 272, 345-359.

${ }_{49}^{48}$ Demercian, L.S., 1996. Halokinesis in evolution of the south of Santos Basin from the Aptian to Upper Cretaceous (A $51^{50}$ halocinese na evolução do sul da Bacia de Santos do Aptiano ao Cretáceo superior). Master Dissertation, Universidade 52 Federal do Rio Grande do Sul, Brazil.

54 $55^{D i a s, ~ J . L ., ~ 1998 . ~ S t r a t i g r a p h i c ~ a n d ~ s e d i m e n t o l o g i c a l ~ a n a l y s i s ~ o f ~ A p t i a n ~ s t a g e ~ i n ~ p a r t ~ o f ~ t h e ~ e a s t e r n ~ m a r g i n ~ o f ~ B r a z i l ~ a n d ~}$ 56 Malvinas Plateau - Considerations about the first marine incursions and ingressions of the South Atlantic Ocean (Análise 58 59 sedimentológica e estratigráfica do andar aptiano em parte da margem leste do Brasil e no Platô das Malvinas - 
considerações sobre as primeiras incursões e ingressões marinhas do oceano atlântico sul meridional). PhD thesis, Universidade Federal do Rio Grande do Sul, Brazil.

1 2Freitas, J.T.R., 2006. Evaporite depositional cycles of the Santos Basin: an analysis of cyclostratigraphy data from two 3 4wells and seismic traces (Ciclos deposicionais evaporíticos da Bacia de Santos: uma análise cicloestratigráfica a partir de 5 6dados de 2 poços e de traços de sísmica). Ph.D thesis, Universidade Federal do Rio Grande do Sul, Porto Alegre, Brazil. 7 8Gamboa, L.A.P., Machado, M.A.P., Silveira, D.P., Freitas, J.T.R., Silva, S.R.P., 2008. Evaporites stratigraphy in the South 9 10Atlantic: interpretation of seismic and tectonic-stratigraphic control in the Santos Basin (Evaporitos estratigráficos no 11 12atlântico sul: interpretação sísmica e controle tectono-estratigráfico na bacia de Santos), in Mohriak, W.U., Szatmari, P., 13 14Anjos, S.M.C. (Eds.), Salt: geology and tectonics. Examples from Brazilian basins (Sal: geologia e tectônica. Exemplos 15 16nas bacias brasileiras), pp. 340-360.

17

18Garcia, S.F.M., 1999. Three-dimensional study of effects of halokinesis in passive margins (Estudo tridimensional de 19 20efeitos da halocinese em margens passivas). Master Dissertation, Universidade Federal de Ouro Preto, Brazil. 21 22Gomes, P.O., Kilsdonk, B., Minken, J., Grow, T., Barragan, R., 2009. The Outer High of the Santos Basin, southern São 23 24Paulo Plateau, Brazil: pre-salt exploration outbreak, paleogeographic setting, and evolution of the syn-rift structures.
25 26 Search and Discovery Article \#10193 (http://www.searchanddiscovery.net/documents/2009/10193gomes/index.htm). 27

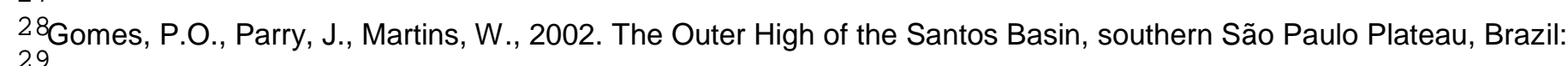
30Tectonic. Am. Assoc. Petrol. Geol. Hedberg Conference, Hydrocarbon habitat of volcanic rifted passive margins, 33 Stavanger, Norway, 8-11.

${ }_{35}^{34}$ Gradstein, F.M., Ogg, J.G., Smith, A.G., 2004. A geologic time scale 2004. Cambridge University Press. ${ }_{37}^{36}$ Gross, G.M., 1972. Oceanography: a view of the Earth. Prentice-Hall, Inc., Englewood, New Jersey. ${ }_{39}^{38}$ Guerra, M.C.M., 2008. Role of halokinesis in controlling structural styles and sediment dispersal pattern in the Santos ${ }_{41}^{40}$ Basin, offshore SE Brazil. PhD thesis, University of Edinburgh, UK, 270. ${ }_{43}^{42}$ Guimarães, P.P., Almeida, H.P., Kowsman, R.O., Costa, M.P. and Boa Hora, M.P., 1982. Gravimetric modelling in São ${ }_{45}^{44}$ Paulo Plateau southern portion and its geological implications (Modelagem gravimétrica na porção sul do Platô de São ${ }_{47}^{46}$ Paulo e suas implicações geológicas). XXXII Brazilian Geological Congress, Salvador, Bahia, 4, 1570 - 1575. ${ }_{49}^{48}$ Henry, S., Brumbaugh, W.D., Cameron, N.R., 1995. Presalt source rock development on Brazil's conjugate margin: West ${ }_{51}^{50}$ African examples. 1st Latin American Geophysical Conference, Rio de Janeiro, August, extended abstract, pp.3. 52 53 Hudec, M.R., Jackson, M.P.A., Schultz-Ela, D.D., 2009. The paradox of minibasin subsidence into salt: clues to the 54

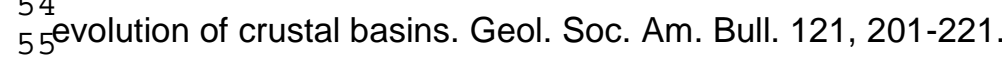

56 57 lan, N., Jackson, M.P.A., Hudec, R., 2009. Tectonics of passive margin salt basins: crustal structure of the Gulf of Mexico 58 59 and South Atlantic during salt deposition. Am. Assoc. Petrol. Geol., Annual Convention and Exhibition, Denver, Colorado, 60 61 Abstract. 
Jackson, M.P.A., Cramez, C., Fonck, J.M., 2000. Role of subaerial volcanic rocks and mantle plumesin creation of South Atlantic margins: implications for salt tectonics and source rocks. Marine and Petroleum Geology, 17, 477-498. 1 2Karner, G.D., 1982. Spectral representation of isostatic models. BMR Journal of Australian Geology, 7, 55-62. 3 4Karner, G.D., Driscoll, N.W., Barker, D.H.N., 2003. Syn-rift regional subsidence across the West African continental 5 Gmargin: the role of lower plate ductile extension, in: Arthur, T.J., MacGregor, D.S., Cameron, N.R. (Eds.), Petroleum 7 8Geology of Africa: New themes and developing technologies. Geological Society, London, Special Publications, 207, 9 10105-129.

11

12Karner, G.D., Gamboa, L.P.A., 2007. Timing and origin of the South Atlantic pre-salt sag basins and their copping 13

14evaporites, in: Schreiber, B., Lugli, S., Babel, M., Evaporites through space and time. Geological Society Special 15 16Publication, 285, 15-35.

17

18Kumar, N., Gamboa, L.A.P., Scheiber, B.C., Mascle, J., 1977. Geologic history and origin of São Paulo Plateau 19 2Q(southeastern Brazilian margin ), comparison with the Angolan margin, and early evolution of the northern South Atlantic. 21

22Initial reports of the Deep Sea Drilling Project. Washington. D.C. 39, 927-945.

23

24Lavier, L.L., Manatshal, G., 2006. A mechanism to thin the continental lithosphere at magma-poor margins. Nature, 440, 25 26324-328.

27

28 Lerche, I., Petersen, K., 1995. Salt and sediments dynamics, CRC Press.
29 .

39Marton, L.G., Tari, G.C., Lehmann, C.T., 2000. Evolution of the Angolan passive margin, West Africa, with emphasis on

32 3 post-salt structural styles, in: Mohriak, W.U., Talwani, M. (Eds.), Atlantic rifts and continental margins. Americam 34 Geophysical Union Geophysical monography, 115, 129-149.

37 Mascle, J.R., Renard, V., 1976. The marginal Sao Paulo Plateau, comparison with the southern Angolan margin. 38 Brazilian Academy of Sciences, 48,179-190.

${ }_{41}^{49}$ McKenzie, D.P., 1978. Some remarks on the development of sedimentary basins. Earth Planet. Sci. Letters, 40, $25-32$. ${ }_{43}^{42}$ Meisling, K.E., Cobbold, P.R., and Mount, V.S., 2001. Segmentation of an obliquely rifted margin, Campos and Santos $45^{\text {basins, }}$ southeastern Brazil. Am. Assoc. Petrol. Geol. Bull. 85, 1903-1924.

${ }_{47}^{46}$ Mohriak, W.U., 2001. Salt tectonics, volcanic centers, fracture zones and their relationship with the origin and evolution of 48 the South Atlantic Ocean: geophysical evidence in the Brazilian and West African margins, in: SBGf, International ${ }_{51}^{50}$ Congress of The Brazilian Geophysical Society, 7, Salvador-Bahia - Brazil, Expanded Abstract, pp. 1594. 52 Mohriak, W.U., Szatmari, P., 2001. Salt tectonics and sedimentation along Atlantic margins: insights from seismic 54

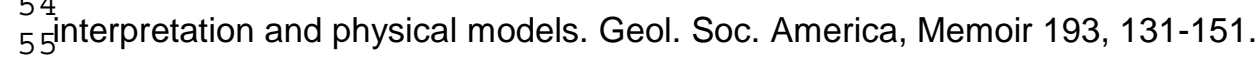

56 57 Moreira, J.P.; Madeira, C.V., Gil, J.A., Machado, M.A.P., 2007. Santos Basin (bacia de Santos), in Stratigraphic charts 58 59 (Cartas estratigráficas). Boletim de Geociências da Petrobras, 15, (2), 531-549.

60

61 
Pereira, M.J., Barbosa, C.M., Agra, J., Gomes, J.B., Aranha, L.G.F., Saito, M., Ramos, M.A., Carvalho, M.D., Stamato,

M., Bagni, O., 1986. Stratigraphy of the Santos Basin: sequences analysis, depositional systems and litho-stratigraphic 1 rrevision (Estratigrafia da Bacia de Santos: Análise das sequências, sistemas deposicionais e revisão lito-estratigráfica). 3 4XXXIV Brazilian Geological Congress, (1), 65-79.

5 6Pereira M.J., Macedo J.M., 1990. Santos Basin: perspectives of a new petroleum province in the Southeastern Brazilian 7 8continental platform (A Bacia de Santos: perspectivas de uma nova província petrolífera na plataforma continental 9 10 sudeste brasileira). Boletim Geociências da Petrobrás, 4, 3-11.

11

12Pereira, M.J., Feijó, F.J., 1994. Santos Basin (Bacia de Santos). Boletim de Geociências da Petrobras, Rio de Janeiro, 8, 13 $14(1), 219-234$.

15

16Pinet, P.R., 1996. Invitation to oceanography. St. Paul, MN, West Publishing Company, ISBN 0-314-06339-0.

17

18Roberts, A.M., Kusznir, N.J., Yielding, G., Styles, P., 1998. 2D flexural backstripping of extensional basins: the need for a 19 20 sideways glance. Petroleum Geoscience, 4, 327-338.

21

22Rouby, D., Cobbold, P.R., Szatmari, P., Demercian, S., Coelho, D., Rici, J.A., 1993. Least-squares Palinspastic 23 ${ }^{24}$ Restoration of Regions of Normal Faulting - Application to the Campos Basin (Brazil). Tectonophysics, $221,439-452$. 25

26Rowan, M.G., 1993. A systematic technique for the sequential restoration of salt structures. Tectonophysics, 228, 33127 28348

29

30 Scotchman, I.C., Marais-Gilchrist G., Souza, F.G., Chaves, F.F., Atterton, L.A., Roberts, A., Kusznir, N.J., 2006. A failed 31 32 sea-floor spreading centre, Santos Basin, Brasil. Rio Oil \& Gas Conference. IBP. Rio de Janeiro, Abstract.

${ }^{34}$ Szatmari, P., Demercian, L.S., 1993. Salt Tectonics in the southern Brazilian margin (Tectônica de sal na margem

36 Sudeste brasileira). SBGf, Congresso Internacional da Sociedade Brasileira de Geofísica, Anais 3,1347-1351.

${ }_{38}^{38}$ Zalán, P.V., Severino, M.C.G., Oliveira, J.A.B., Magnavita, L.P., Mohriak, W.U., Gontijo, R.C., Viana, A.R., Szatmari, P., ${ }_{41}^{40}$ 2009. Stretching and thinning of the upper lithosphere and continental-oceanic crustal transition in Southeastern Brazil. ${ }_{43}^{42} \mathrm{Am}$. Assoc. Petrol. Geol., International Conference and Exhibition, Rio de Janeiro, Brazil, Abstract.

${ }_{45}^{44}$ Watts, A.B., 1982.Tectonic subsidence, flexure and global changes in sea level. Nature, 297, 469-474.

46 Williams, B.G. and Hubbard, R.J., 1984. Seismic stratigraphic framework and depositional sequences in the Santos ${ }_{49}^{48}$ Basin, Brazil. Marine Petrol. Geol., 1, (2), 90-104

${ }_{51}^{50}$ Weijermars, R.; Jackson, M.P.A., Vendeville, B.C., 1993. Rheological and tectonic modeling of salt provinces.

52 53 Tectonophysics $217,143-174$.

54 55 Wernicke, B., 1981. Low-angle normal faulls in the Basin and Range Province: nappe tectonics in an extending orogen. 56 57 Nature, 291, 645-648. 
Fig. 1 - Regional location map outlining the study area (red polygon) including two restored sections (black lines), six available wells (yellow circles) and four studied pseudo-wells (red circles). Notice the aborted spreading center in the southern region, and its northward propagation along a pre-salt fault trend. Its possible continuity within the study area could account for a local crustal thinning $1^{\text {anomaly. }}$

2Fig. 2 - Simplified stratigraphic chart of the Santos Basin outlining the fiveteen horizons interpreted in the seismic profiles during the 4 study. The major Early Cretaceous progradation event is highlighted between the horizons 03 and 08.

5Figure 3 - The two geological sections A-A' and B-B' (see location in Fig. 1) are based on fifteen interpreted horizons. The ten layers 6 above the salt are intensely deformed. The Cabo Frio Fault separates extensional and compressive domains. A proximal low and an 7intermediate high constitute inherited structures, developed before the onset of salt tectonics. Classical minibasins occur in the distal 8compressional domain.

9

10 Figure 4 - Schematic block diagram of the Santos Basin adapted from the model of Lavier and Manatshal (2006). Notice the aborted

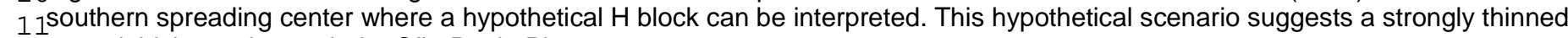

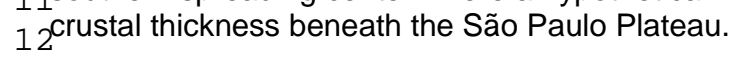

13

$14^{13}$ Figure 5 - The section A-A' is projected on the more regional section A-B-C modified from Carminatti et al. (2008). In the

15 compressional domain, extending eastwards the study area, the evaporites were removed from the more proximal regions and 15 transported towards more distal portions of the margin as mobile blocks, creating accomodation space for the overlying sedimentary 16 pile.

18 Figure 6 - The shelf break (white points) and foot of the slope (black points) are shown here for the section B-B'. These critical points 19 have been interpreted for each restored horizon above the salt layer, including the Albian carbonates top (H9). Notice the Cabo Frio 20 Fault which limits the thicker proximal domain from the post-salt minibasins that developed in the more distal domain.

21

22Figure 7 - Example of the first restoration steps showing sequential sketches for the partial results of the section A-A'. Notice two 23 desired anchor points of overlying post-salt layers (salt windows), which are highlighted in the step 3 , as well as an exaggerated 24 spacing point of the isostasy response to adjustment of the salt layer remarked in the step 4.

25

26 Figure 8 - Restoration outcomes of pre-salt stages applied without paleobathymetric data to sections A-A' and B-B'. Notice the 27 extension restored represent less than $10 \%$ from the deformed section. The result mountainous terrain reaching up 3,000 meters high 28 in the section A-A' is consistent with the accommodation space needed for the thick salt layer deposition.

29 Figure 9 - Sections A-A' and B-B' restored at the salt deposition stage. The obtained scenario shows an original salt layer up to 4,000 30 meters thick in the section A-A'. The faint pink color represents the amount of salt added in order to restore the salt motion towards $31_{\text {distal portions. }}$

32

33Figure 10 - Restored profiles of sections A-A' and B-B' for the Albian to Cenomanian stages that shows a climax of the rafting 34tectonics. The fast extension of the thin Albo-Cenomanian layers is obtained by the underlying salt layer movement, pushed to distal 35 portions by the thick post-salt sediments deposition in the proximal area.

36

36 Figure 11 - Restoration model for the Albian carbonates. The seismic image shows the present day configuration of the Albian growth 38 structures. The restoration model requires a formerly thicker salt basin (thicker than 2,500 m) to accommodate the observed thickness 39 growing of the carbonate layers.

40 Figure 12 - The progradation of the Late Cretaceous restored outcomes for sections A-A' and B-B' showing the development of the ${ }^{41}$ Cabo Frio Fault (black arrows) in relashionship to the total extention in the study area (red arrows). In association with this diferential 42lateral deformation, the first salt windows were formed in many compartments.

43

44Figure 13 - Restored outcomes of the most recent layers for sections A-A' and B-B'. These sections show that salt tectonics is no 45longer active in the proximal domain, and remained relatively quiescent within the more distal domain, developing the minibasins. 46

47 Figure 14 - First restoration steps showing the decompacted Miocene situation just after the removal of the uppermost layer. The 48 present day in details images is compared with the decompacted scenario of the central image. The decompaction outcome,

49 dependent of the isostatic parameterization, is refered to the present day referential bathymetry (diference in the striped grey area).

49 The detail 1 highlights an isostatic result locally higher than the referential bathymetry (potential erosion) while the detail 2 highlights a 51 relatively lower isostatic position in the minibasins domain (potential aggradation).

52Figure 15 - Paleo-bathymetry model through time based on well data for the platform and slope regions (no data available to the 53 continental rise region). The grey area is a superposition of all well data in each area. The red dashed lines are regional bathymetry 54 models for each region. Colored circles (blue, green and red) show the bathymetry expected for each restored age. Notice the pre55 existing interpreted depression preceding the deposition of salt.

56

57 Figure 16 - Seismic image showing a possible cap rock over the proximal diapirs. Episodes of differential compaction in the post-sal 58 series are observed in the flanks of salt diapirs, surrounding these sub-outcropping structures and delineating local conditions for $59^{\text {progressive unconformities. }}$

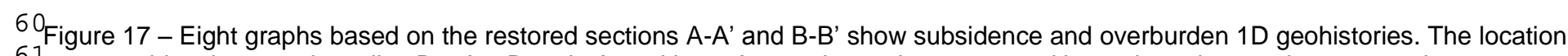

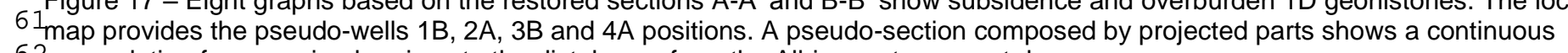
62 progradation from proximal regions to the distal ones from the Albian up to present day. 


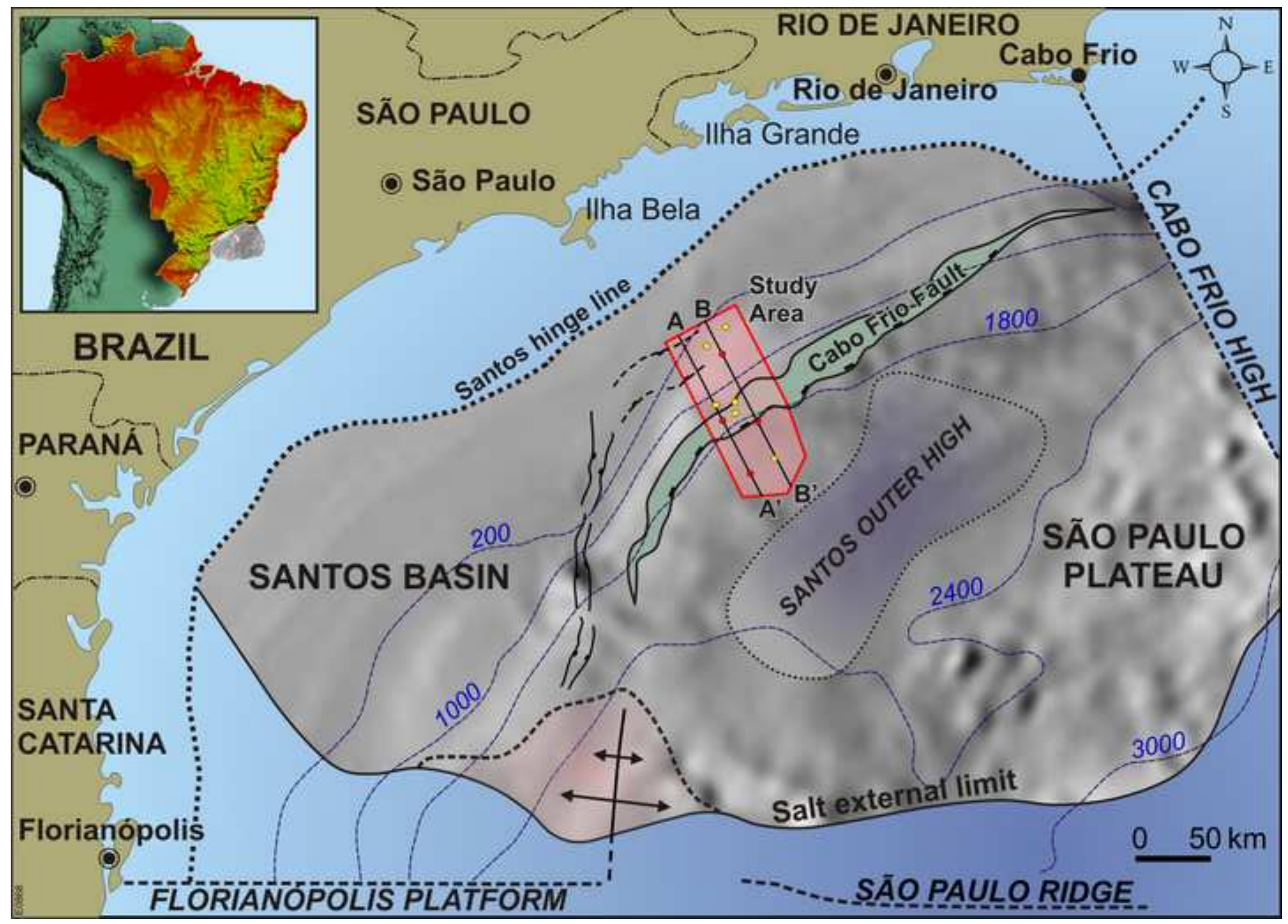




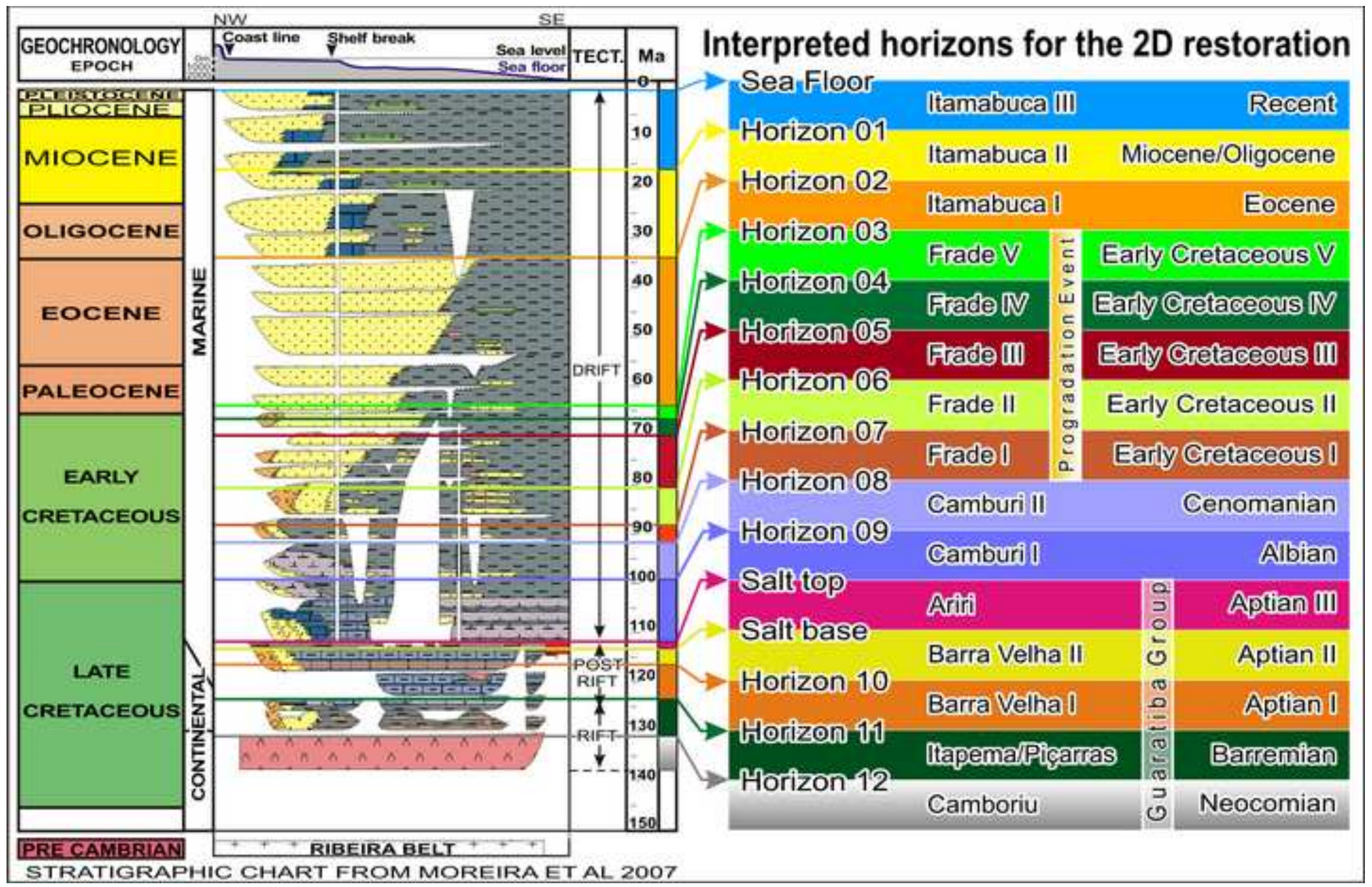


Click here to download high resolution image

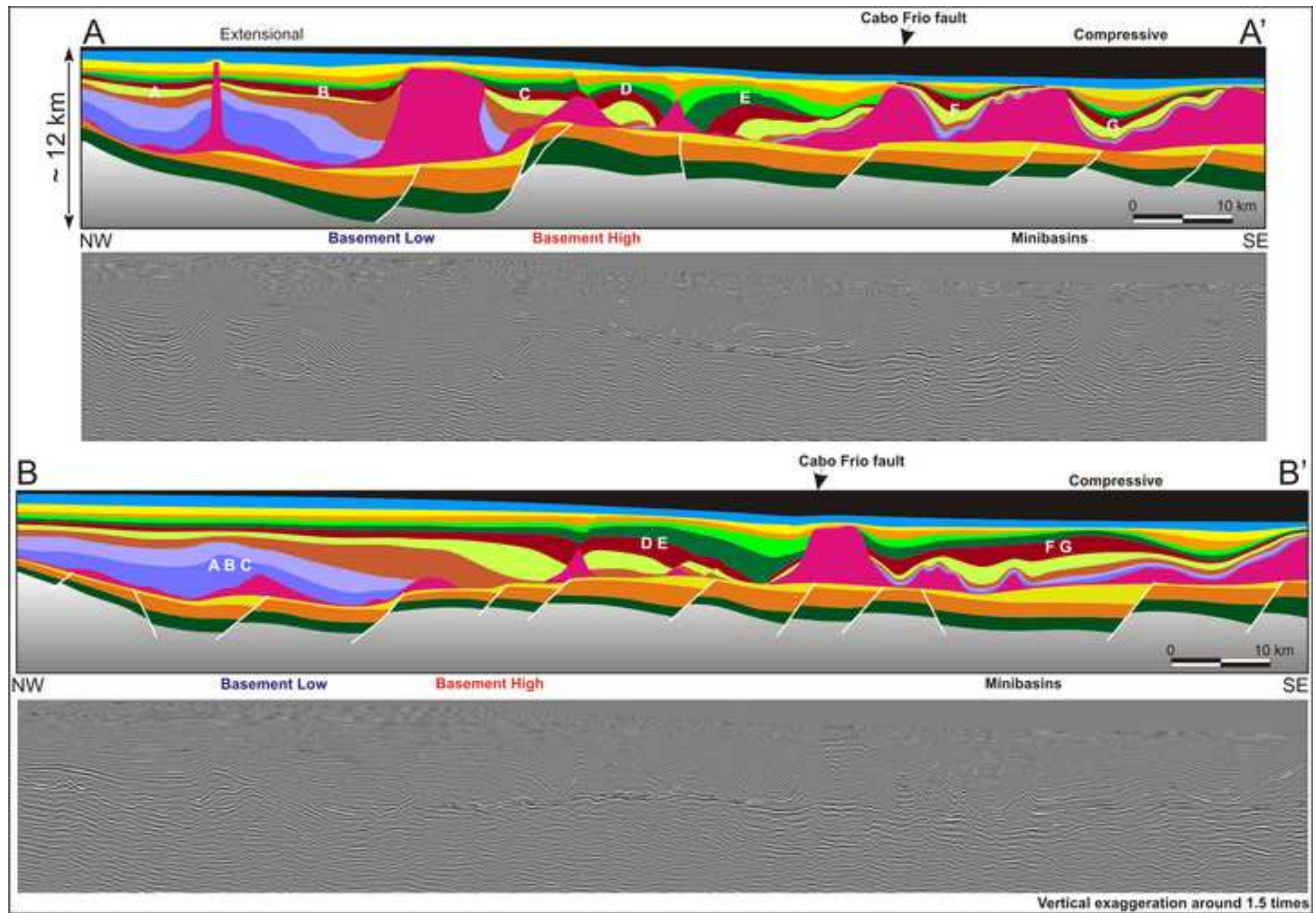




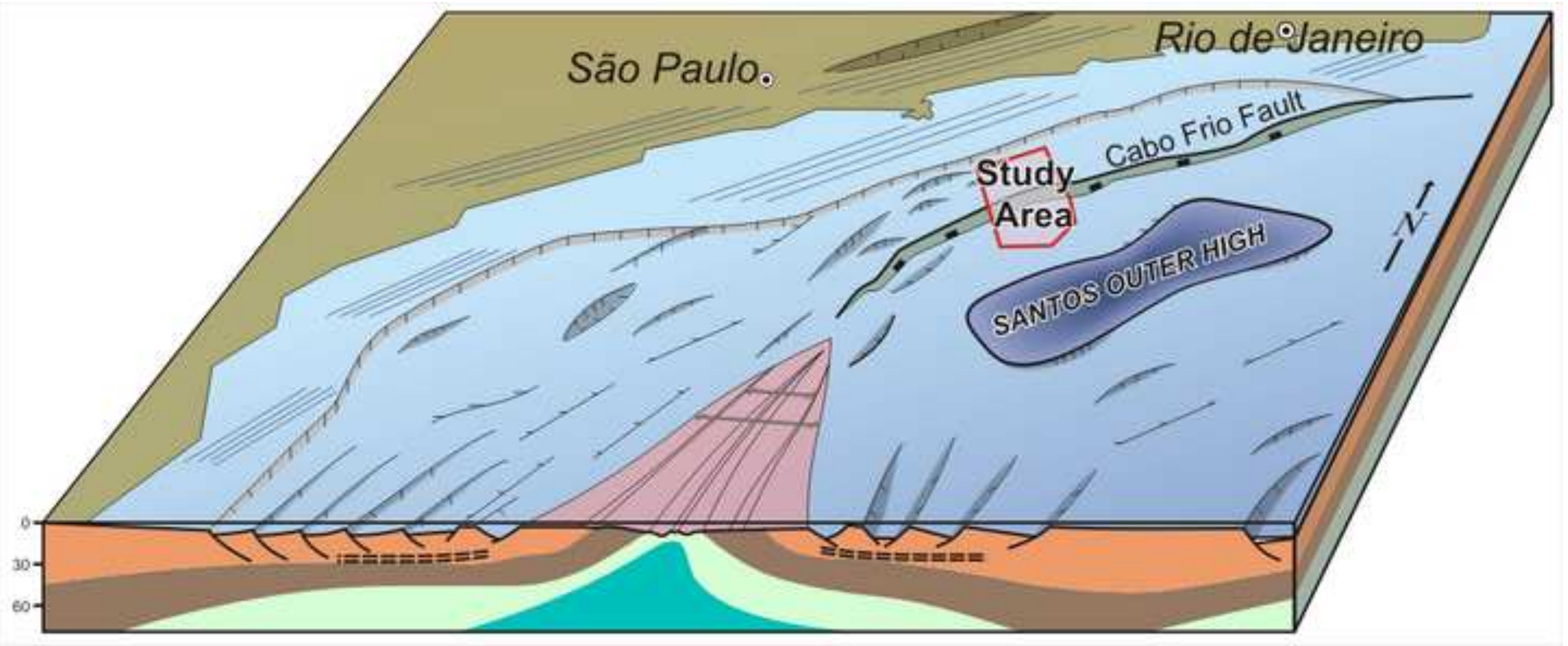




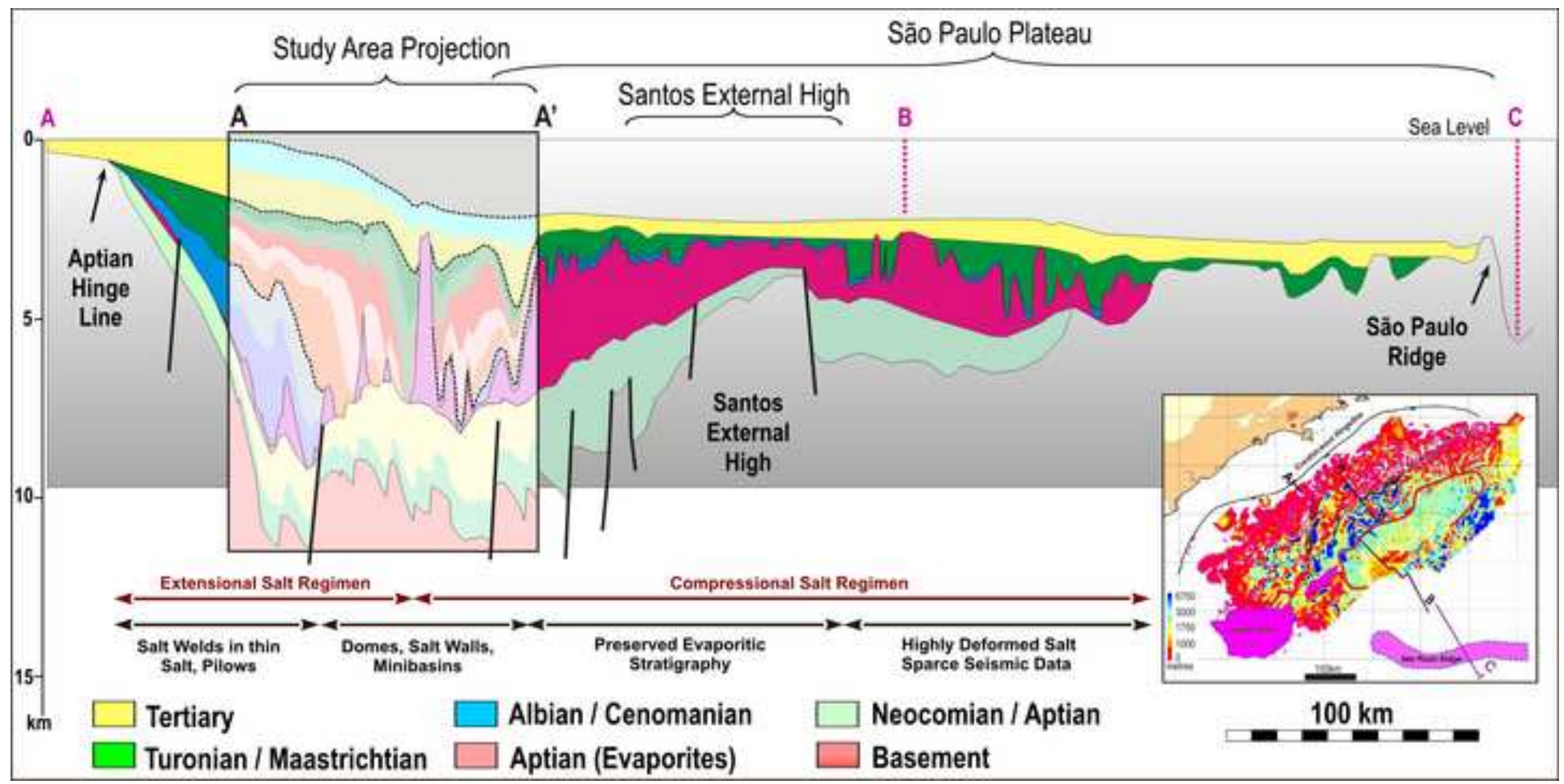


Click here to download high resolution image

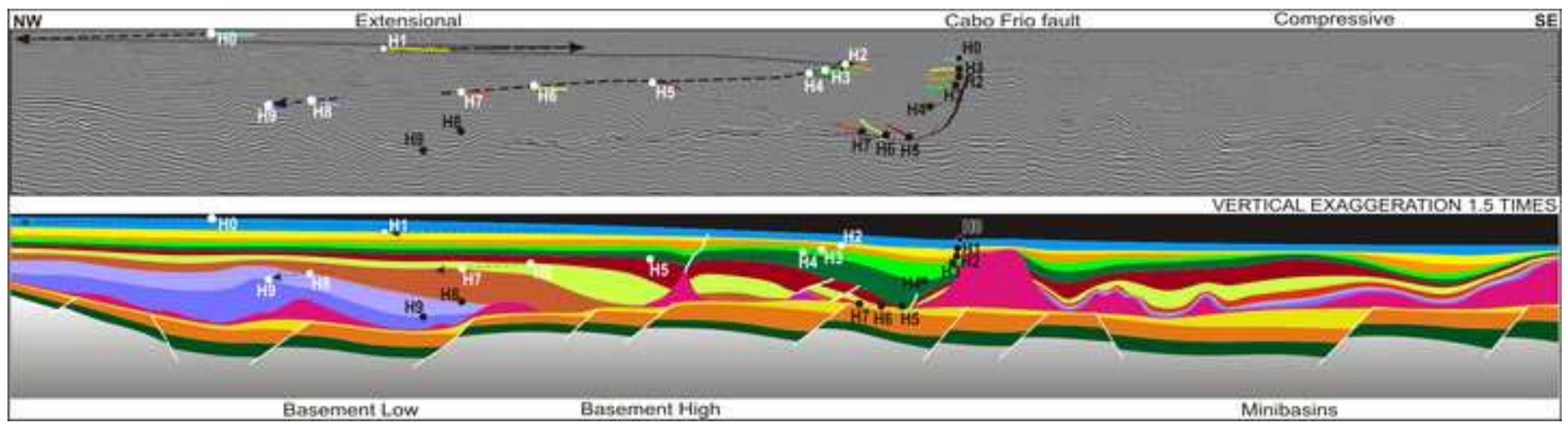


Click here to download high resolution image

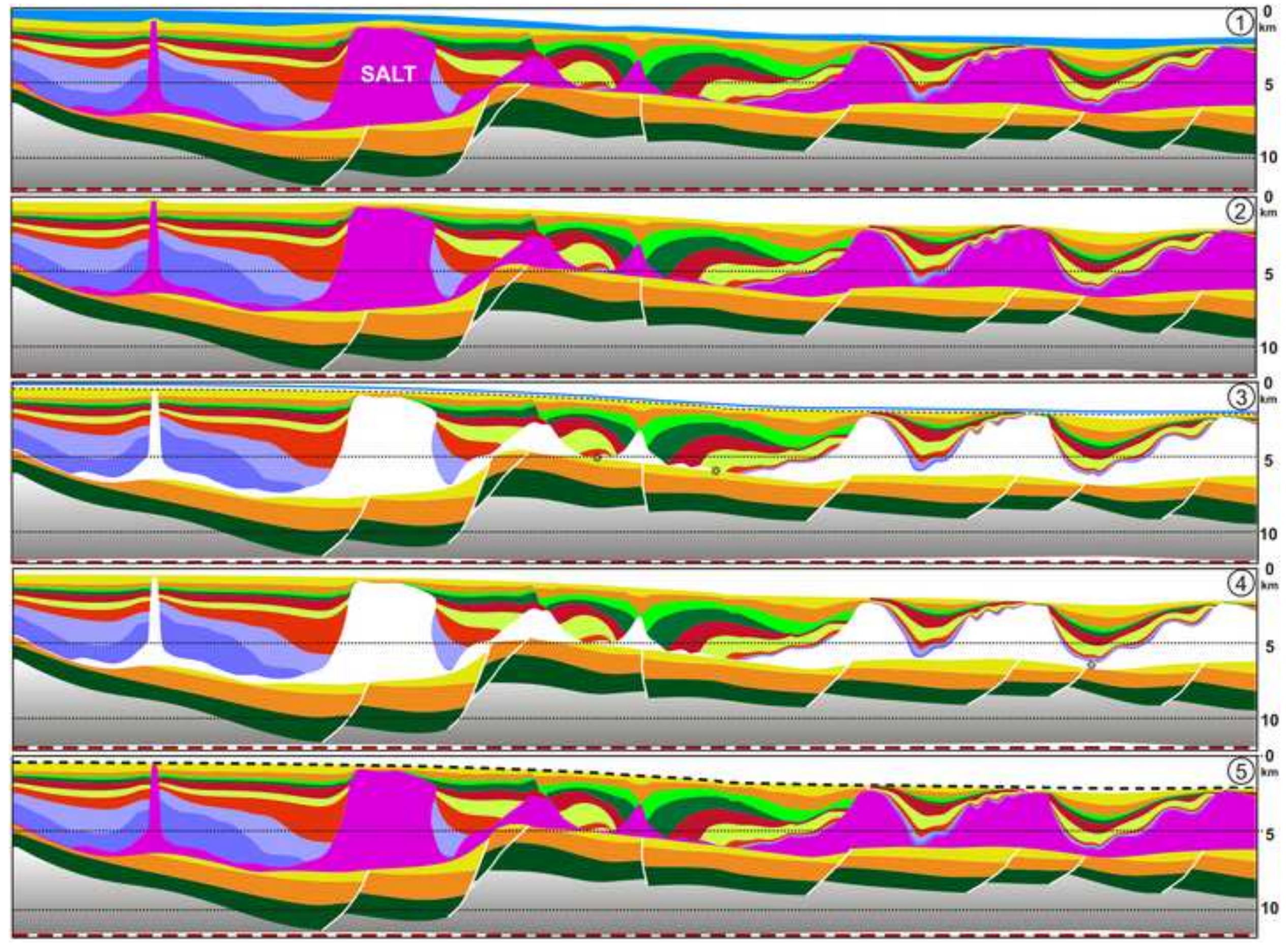


Click here to download high resolution image
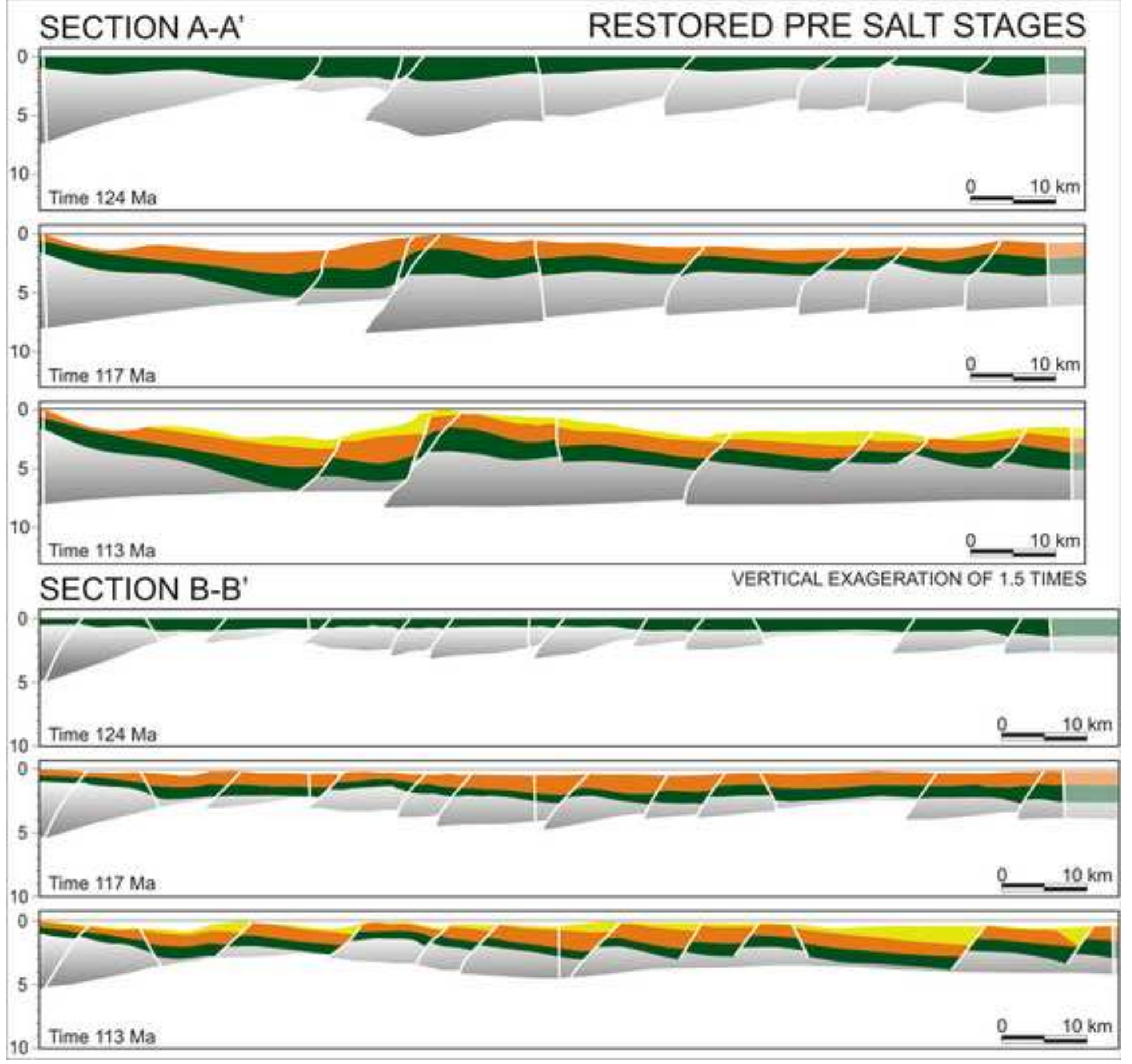


\section{SECTION A-A'}

\section{RESTORED SALT DEPOSITION STAGE}

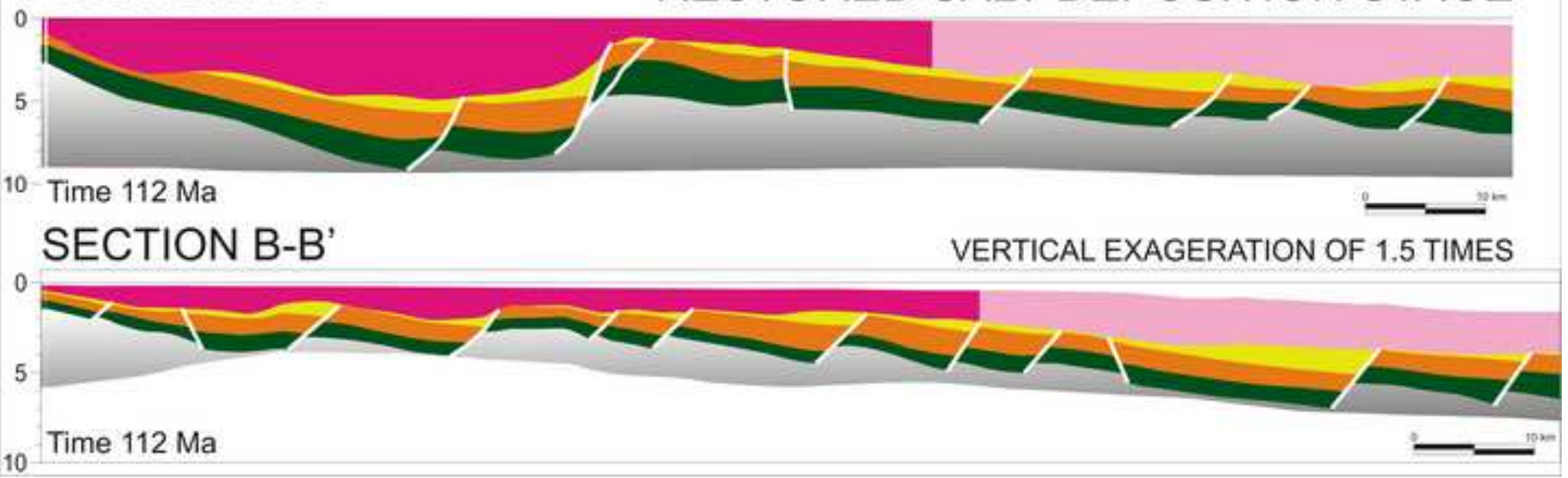


Click here to download high resolution image

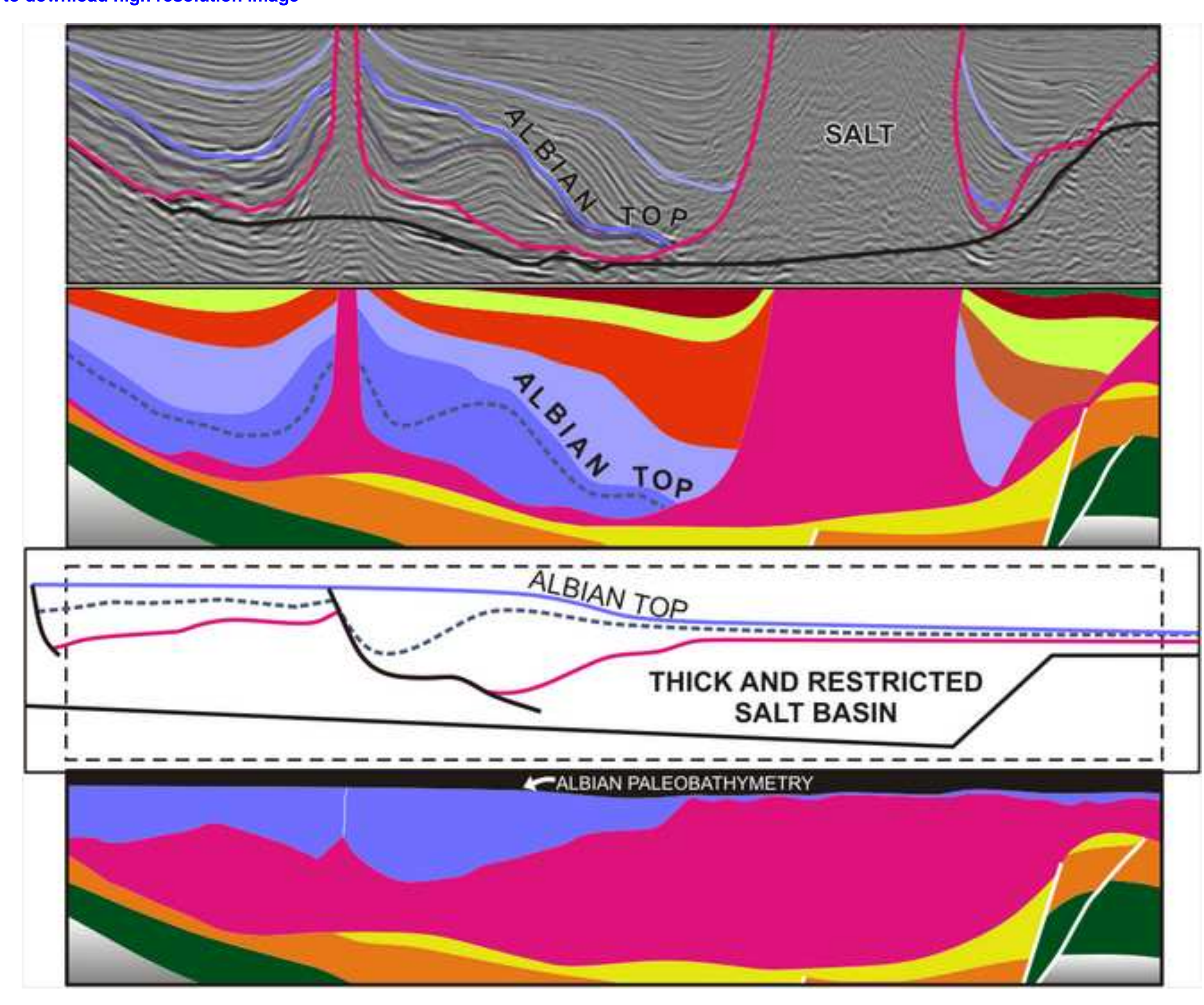

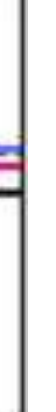

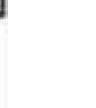


Figure 12
Click here to download high resolution image

Figure 12
Click here to download high resolution image

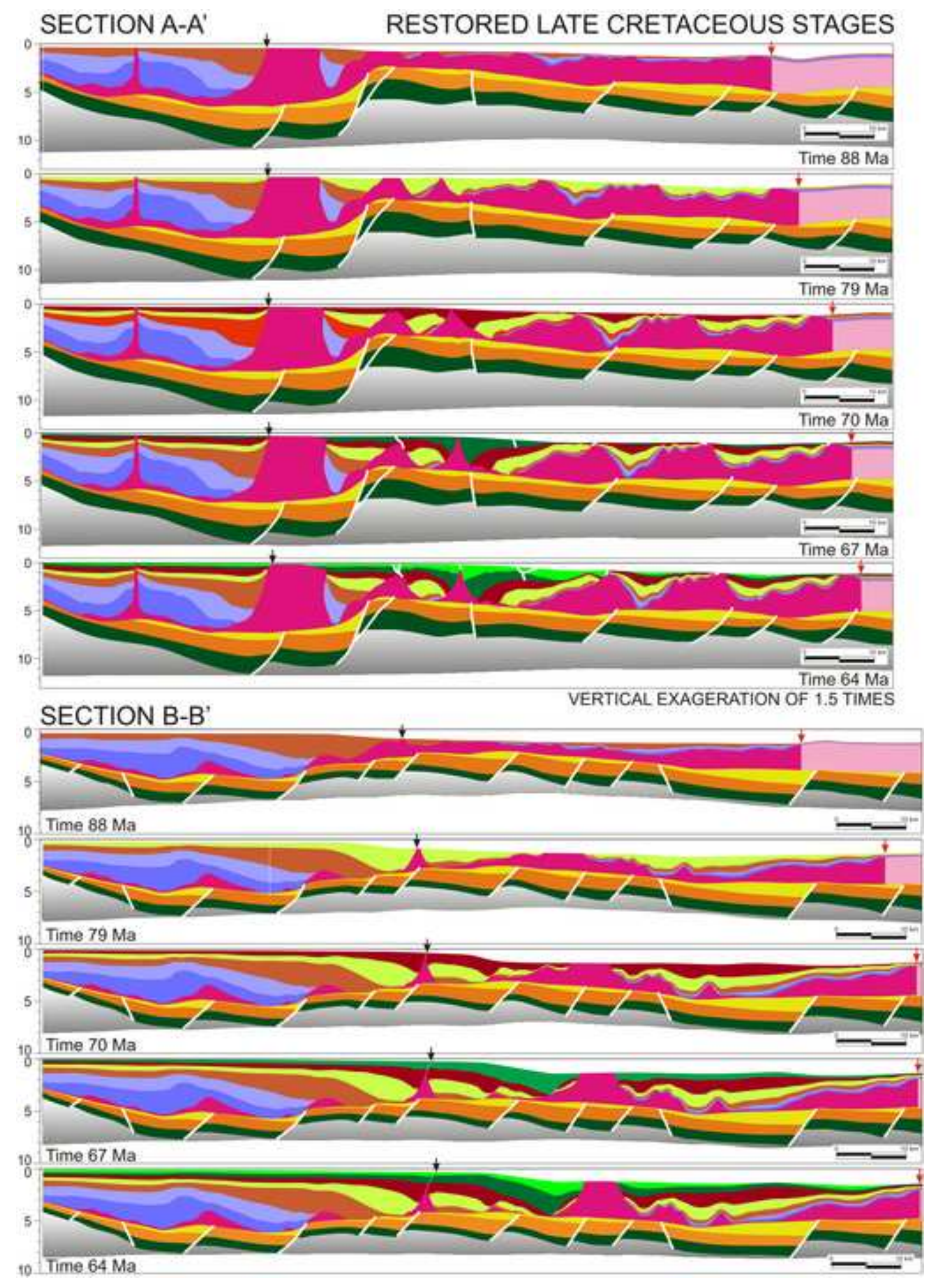

\section{SECTION B-B'}

VERTICAL EXAGERATION OF 1.5 TIMES

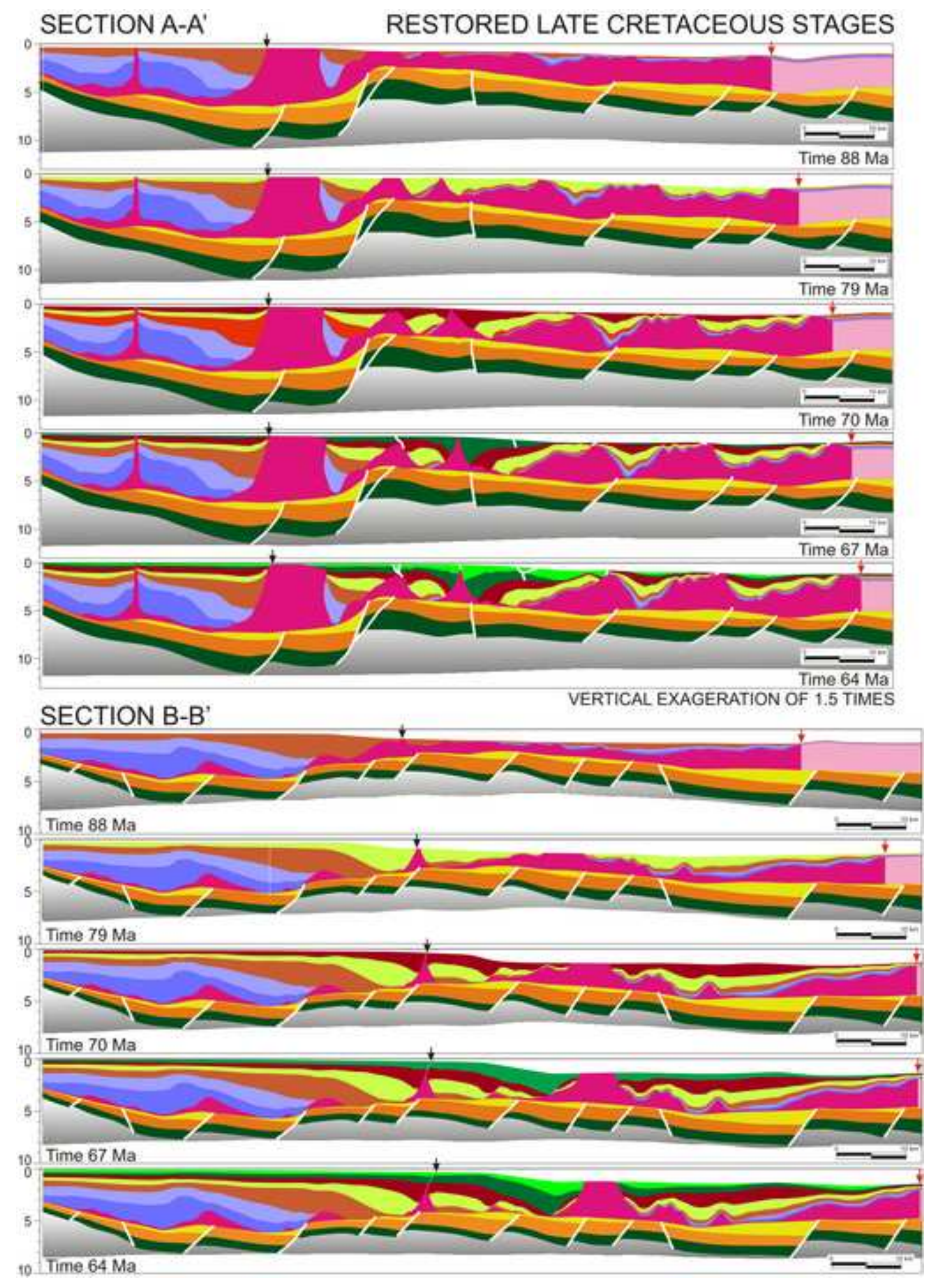

10. Time $64 \mathrm{Ma}$ 
Click here to download high resolution image

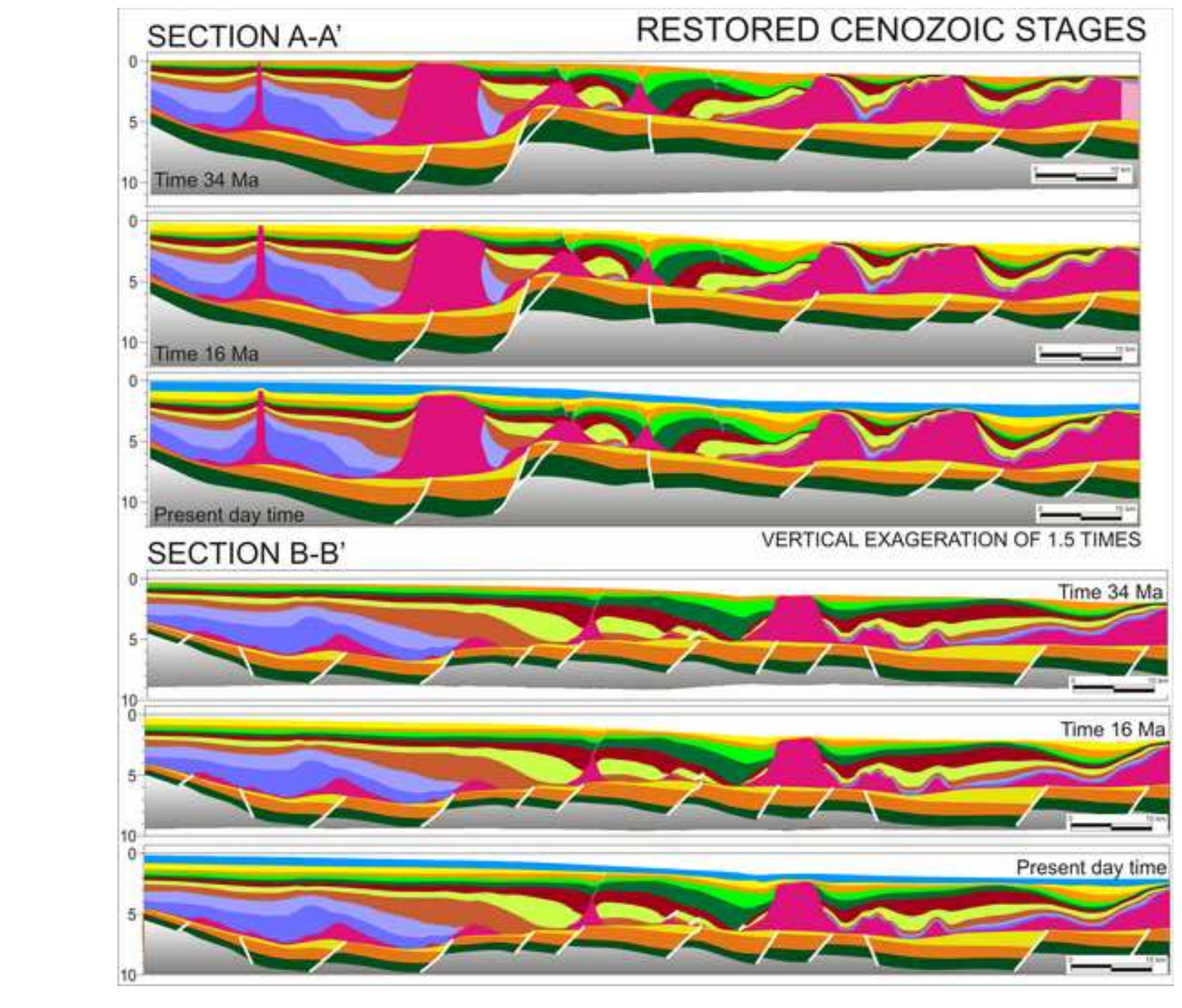


Click here to download high resolution image

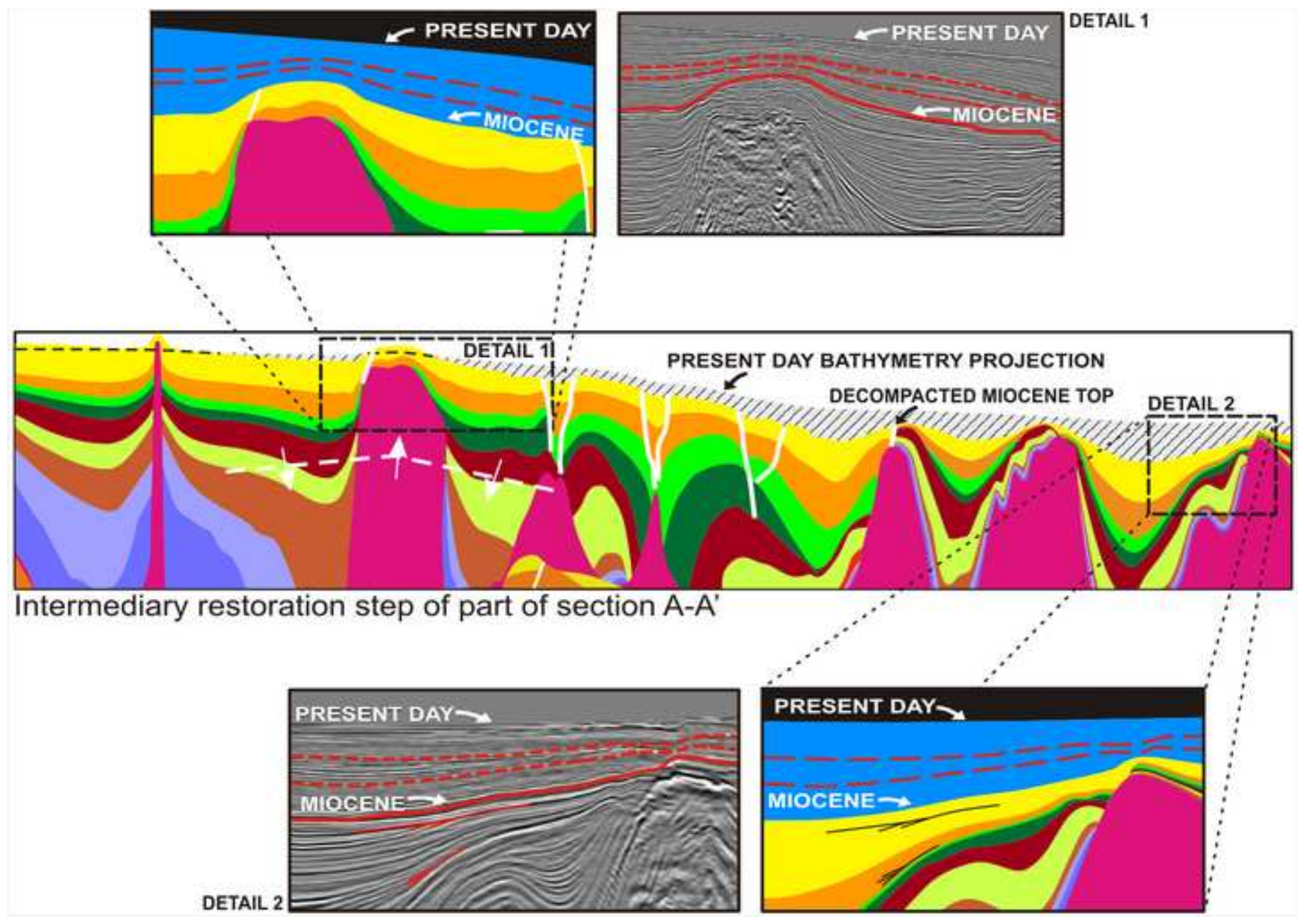

DETAIL 2 
Click here to download high resolution image

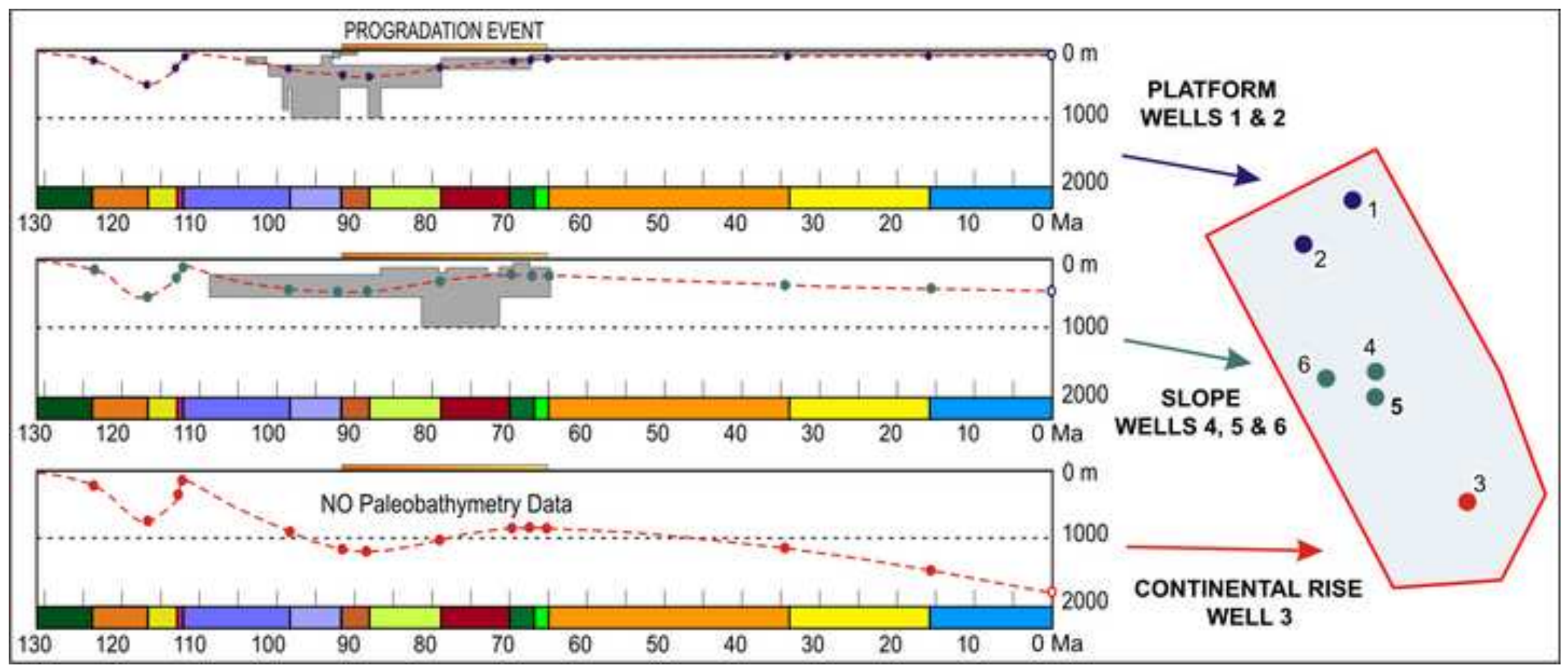


Click here to download high resolution image

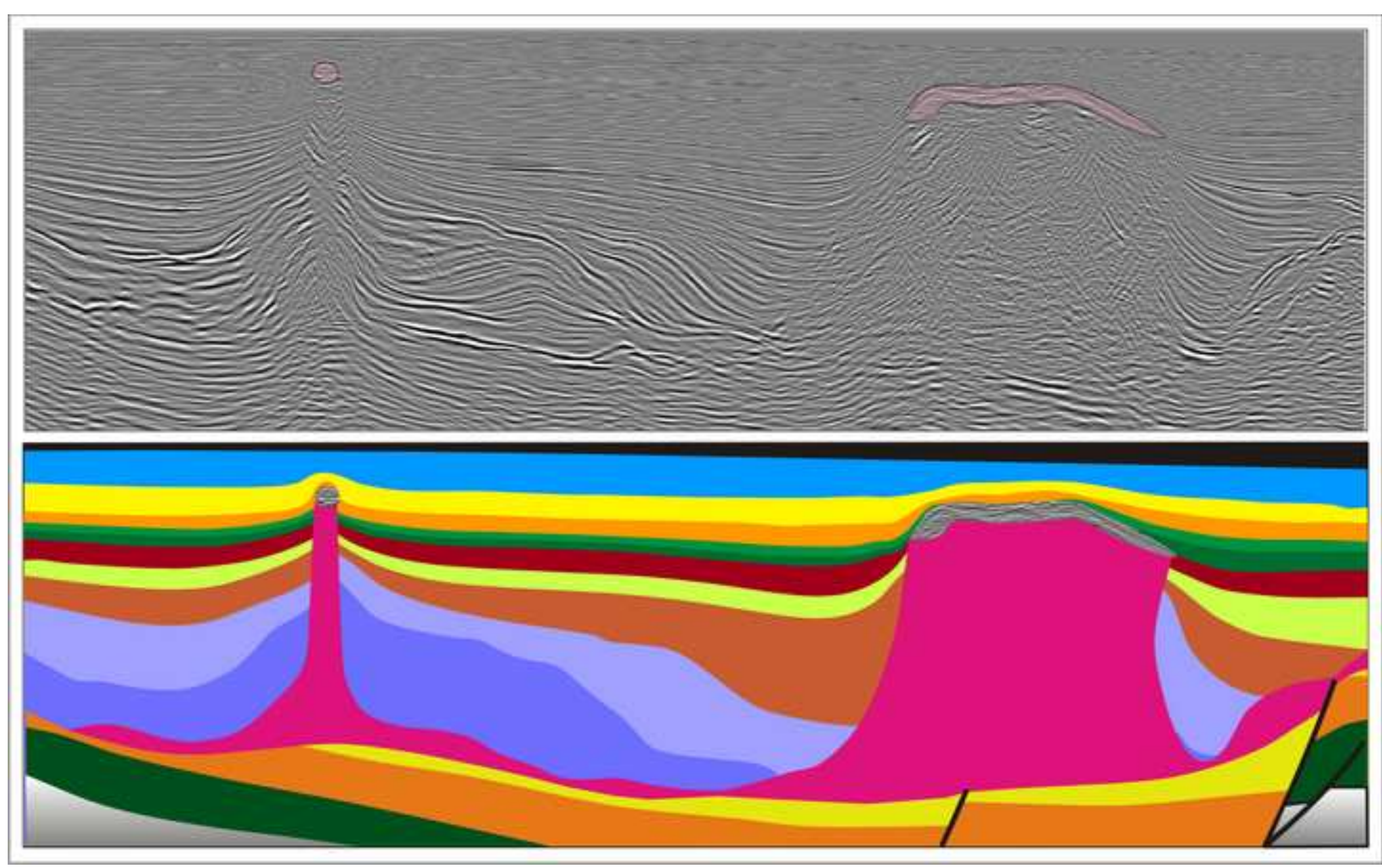


Figure 17

Click here to download high resolution image

\section{PSEUDOWELLS 1D ANALYSIS}

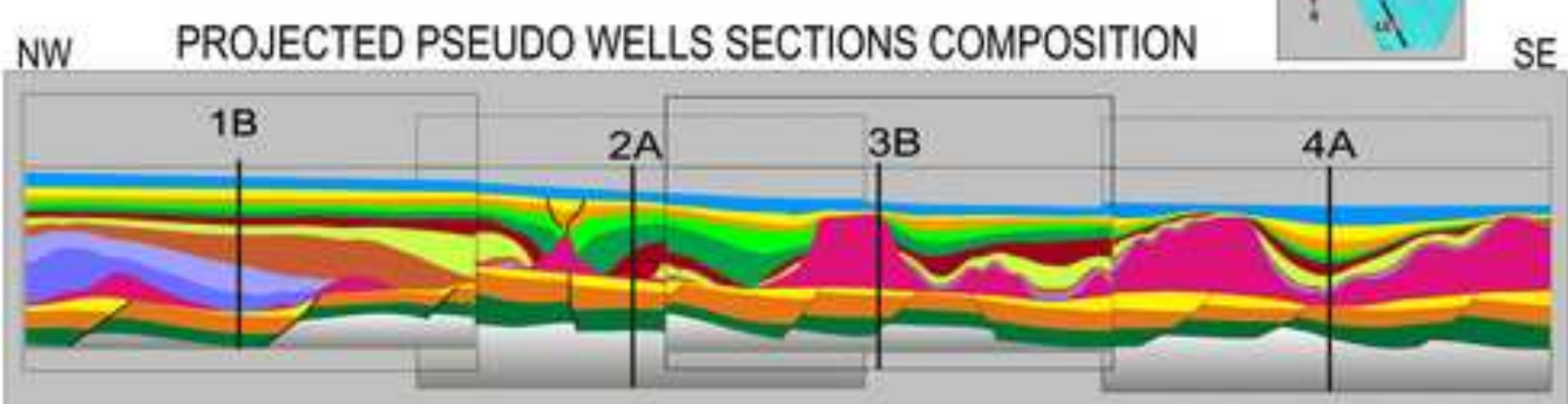

\section{SUBSIDENCE GEOHISTORY}

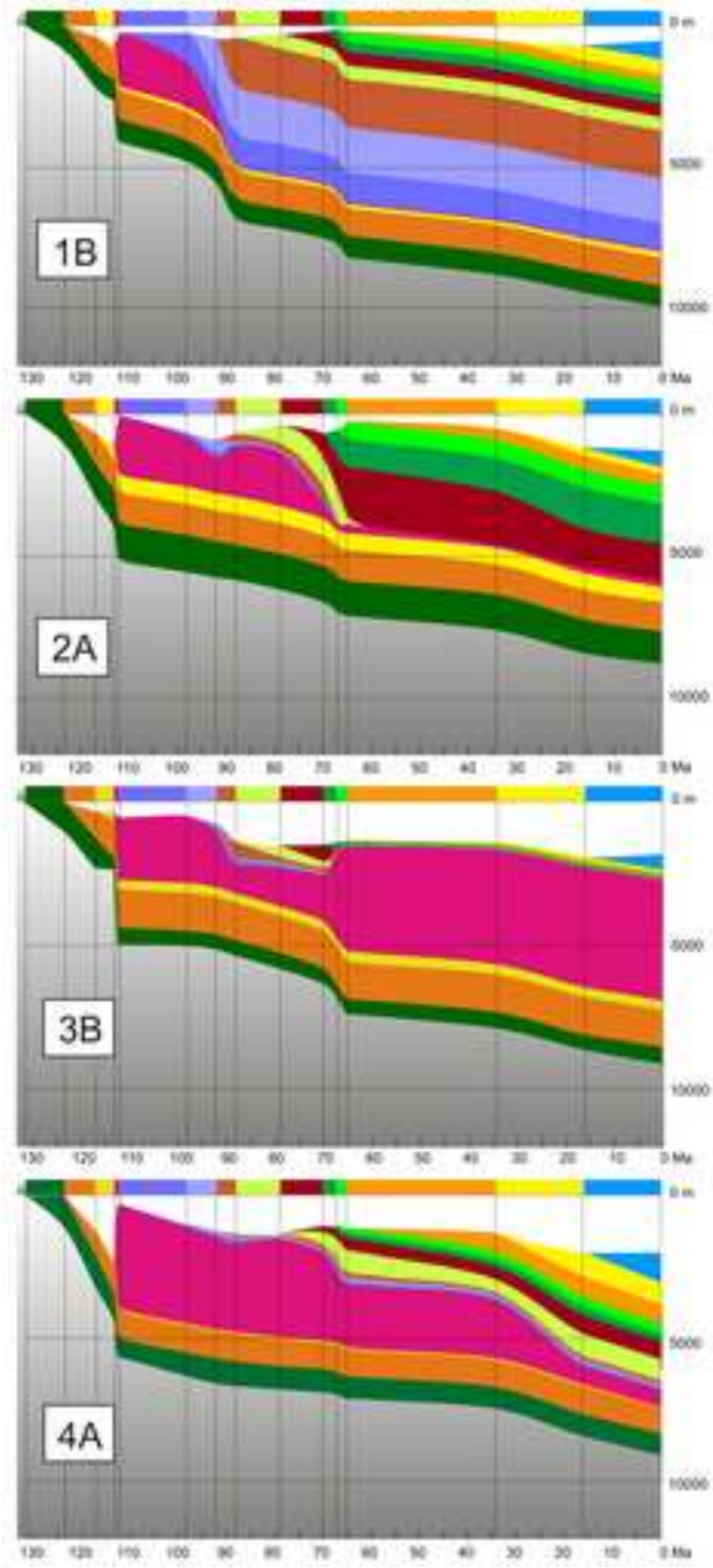

\section{OVERBURDEN GEOHISTORY}

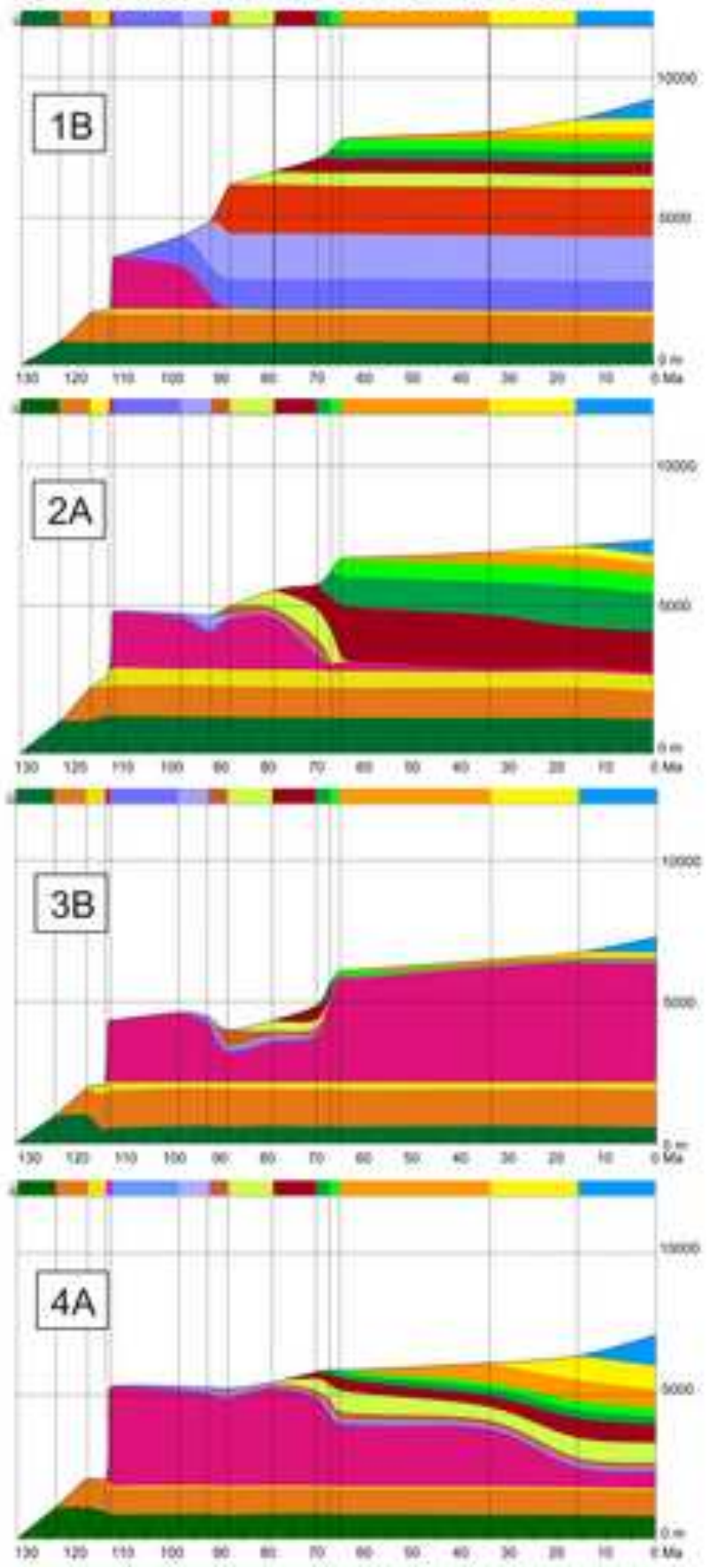

